Temporal and Spatial Distribution of Endangered Juvenile Lost River and Shortnose Suckers in Relation to Environmental Variables in Upper Klamath Lake, Oregon: 2008 Annual Data Summary

Open-File Report 2010-1051 



\section{Temporal and Spatial Distribution of Endangered Juvenile Lost River and Shortnose Suckers in Relation to Environmental Variables in Upper Klamath Lake, Oregon: 2008 Annual Data Summary}

By Summer M. Burdick and Scott P. Vanderkooi

Open-File Report 2010-1051 


\section{U.S. Department of the Interior \\ KEN SALAZAR, Secretary}

\section{U.S. Geological Survey \\ Marcia K. McNutt, Director}

U.S. Geological Survey, Reston, Virginia: 2010

For more information on the USGS-the Federal source for science about the Earth, its natural and living resources, natural hazards, and the environment, visit http://www.usgs.gov or call 1-888-ASK-USGS.

For an overview of USGS information products, including maps, imagery, and publications, visit $h$ ttp://www.usgs.gov/pubprod

To order this and other USGS information products, visit http://store.usgs.gov

Suggested citation:

Burdick, S.M, and Vanderkooi, S.P., 2010, Temporal and spatial distribution of endangered juvenile Lost River and shortnose suckers in relation to environmental variables in Upper Klamath Lake, Oregon: 2008 annual data summary: U.S. Geological Survey Open-File Report 2010-1051, 36 p.

Any use of trade, product, or firm names is for descriptive purposes only and does not imply endorsement by the U.S. Government.

Although this report is in the public domain, permission must be secured from the individual copyright owners to reproduce any copyrighted material contained within this report. 


\section{Contents}

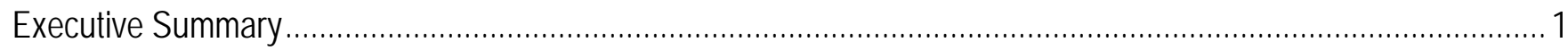

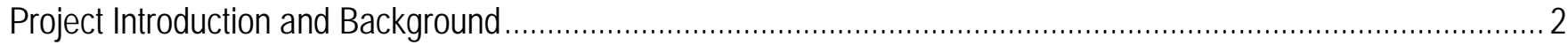

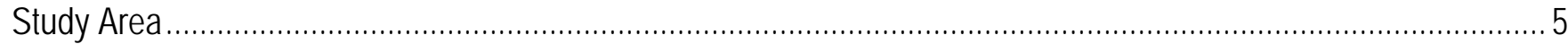

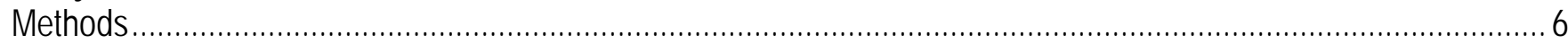

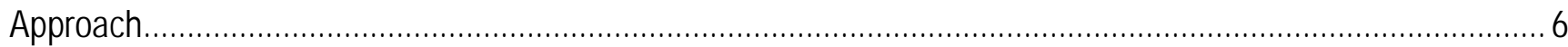

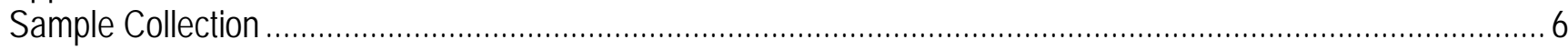

Water-Quality Data.

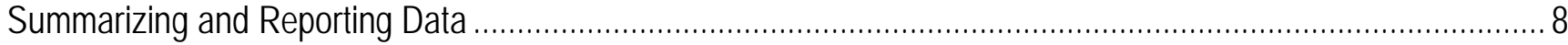

Results of Sample Collection and Data Summary .................................................................................. 8

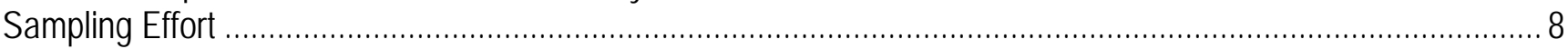

Summary of Water-Quality Conditions ..............................................................................................

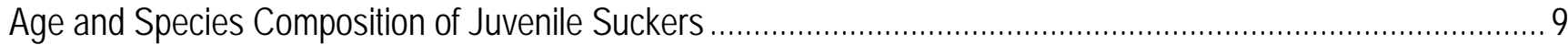

Spatial-Temporal Patterns in Age-1 and Age-2 Sucker Catches............................................................... 9

Spatial-Temporal Patterns in Age-0 Sucker Catches ......................................................................... 10

Juvenile Sucker Condition........................................................................................................ 11

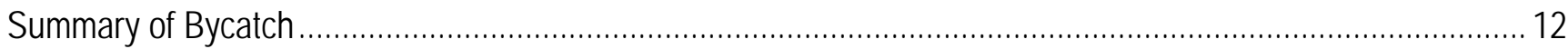

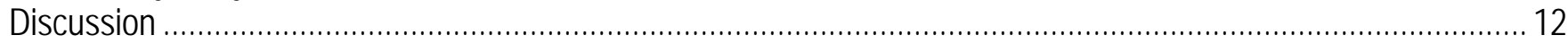

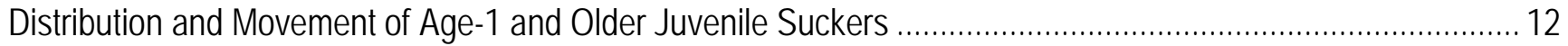

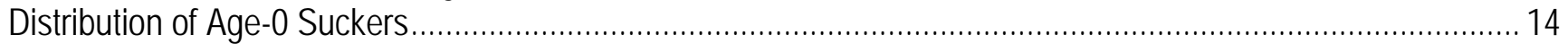

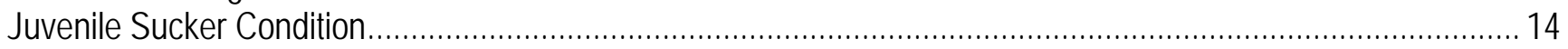

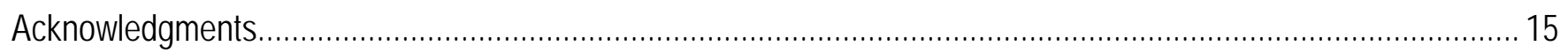

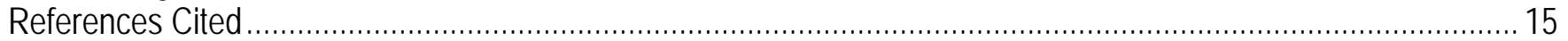

\section{Figures}

Figure 1. Map of Upper Klamath Lake study area and three defined areas of the lake

Figure 2. DO concentrations and temperature recorded each hour at three water-quality

monitoring stations in Upper Klamath Lake, Oregon

Figure 3. Mean weekly catch per unit effort for age-1 suckers caught in trap nets set overnight in

Upper Klamath Lake, Oregon, between May 5 and September 13, 2008.

Figure 4. Mean weekly catch per unit effort for age-1 suckers caught in trap nets set overnight in Upper Klamath Lake, Oregon, between May 5 and September 13, 2008.

Figure 5. Location of sample sites and age-1 and age-2 sucker catch rates in Upper Klamath Lake, Oregon, by week.

Figure 6. Depth for trap net sample sites (A), sites where age-0 suckers were caught (B), sites where age-1 suckers were caught (C), and sites where age-2 suckers were caught (D) are shown by week.

Figure 7. Standard lengths of juvenile suckers collected in traps nets set in Upper Klamath Lake, Oregon, between May 5 and September 12, 2008

Figure 8. Mean weekly catch per unit effort for age-0 suckers caught in trap nets set overnight in Upper Klamath Lake, Oregon, between June 22 and September 13, 2008.

Figure 9. Mean weekly catch per unit effort for age-0 suckers caught in trap nets in three off-shore areas of Upper Klamath Lake, Oregon, between June 22 and August 2, 2008

Figure 10. Mean weekly catch per unit effort for age-0 suckers caught in trap nets in three near-shore areas of Upper Klamath Lake, Oregon, between June 22 and September 13, 2008 
Figure 11. Mean catch per unit effort by 1 meter depth bins for age-0 and age- 1 suckers caught in Upper Klamath Lake, Oregon

Figure 12. Standard length of age-0 suckers caught in trap net sampling in three areas of Upper

Klamath Lake, Oregon, between July 6 and September 13, 2008.

Figure 13. Mean weekly catches of fish other than sucker species captured in trap nets set overnight in

three areas of Upper Klamath Lake, Oregon

\section{Tables}

Table 1. Number of sample sites for juvenile fish visited one to six times in Upper Klamath Lake,

Oregon, 2008

Table 2. Number of sites at which one, two, or three nets were set in three seasons, and in six strata

Upper Klamath Lake, Oregon, 2008

Table 3. Age-1 and age-2 suckers per net captured in trap net sampling in Upper Klamath Lake, Oregon, between May 5 and June 19, 2008 
Conversion Factors, Datum, and Abbreviations and Acronyms

\section{Conversion Factors}

SI to Inch/Pound

\begin{tabular}{lll}
\hline \multicolumn{1}{c}{ Multiply } & By & \multicolumn{1}{c}{ To obtain } \\
\hline centimeter (cm) & Length & \\
millimeter (mm) & 0.3937 & inch (in.) \\
meter (m) & 0.03937 & inch (in.) \\
kilometer $(\mathrm{km})$ & 3.281 & foot (ft) \\
kilometer $(\mathrm{km})$ & 0.6214 & mile (mi) \\
meter (m) & 0.5400 & mile, nautical (nmi) \\
\hline & 1.094 & yard (yd) \\
\hline square meter $\left(\mathrm{m}^{2}\right)$ & Area & \\
square kilometer $\left(\mathrm{km}^{2}\right)$ & 0.0002471 & acre \\
& 0.3861 & square mile (mi $\left.{ }^{2}\right)$ \\
\hline liter (L) & Volume & \\
liter (L) & 33.82 & ounce, fluid (fl. oz) \\
liter (L) & 2.113 & pint (pt) \\
liter (L) & 1.057 & quart (qt) \\
liter (L) & 0.2642 & gallon (gal) \\
\hline & 61.02 & cubic inch (in $\left.{ }^{3}\right)$ \\
\hline gram (g) & Mass & \\
\hline & 0.03527 & ounce, avoirdupois (oz) \\
\hline
\end{tabular}

Temperature in degrees Celsius $\left({ }^{\circ} \mathrm{C}\right)$ may be converted to degrees Fahrenheit ( $\left.{ }^{\circ} \mathrm{F}\right)$ as follows: ${ }^{\circ} \mathrm{F}=\left(1.8 \mathrm{x}^{\circ} \mathrm{C}\right)+32$.

\section{Datum}

Vertical coordinate information is referenced to the North American Datum of 1983 (NAD83). 
Abbreviations and Acronyms

\begin{tabular}{ll}
\hline \multicolumn{1}{c}{ Abbreviations } & \multicolumn{1}{c}{ Meaning } \\
\hline CPUE & catch per unit effort \\
DO & DO \\
PIT & passive integrated transponder \\
SE & standard error \\
SL & standard length \\
TNC & The Nature Conservancy \\
USGS & U.S. Geological Survey \\
\hline
\end{tabular}




\section{Temporal and Spatial Distribution of Endangered Juvenile Lost River and Shortnose Suckers in Relation to Environmental Variables in Upper Klamath Lake, Oregon: 2008 Annual Data Summary}

By Summer M. Burdick and Scott P. VanderKooi

\section{Executive Summary}

Lost River sucker (Deltistes luxatus) and shortnose sucker (Chasmistes brevirostris) were listed as endangered in 1988 for a variety of reasons including apparent recruitment failure. Upper Klamath Lake, Oregon, and its tributaries are considered the most critical remaining habitat for these two species. Age-0 suckers are often abundant in Upper Klamath Lake throughout the summer months, but catches decline dramatically between late August and early September each year and age-1 and older sub-adult suckers are rare. These rapid declines in catch rates and a lack of substantial recruitment into adult sucker populations in recent years suggests sucker populations experience high mortality between their first summer and first spawn. A lack of access to, or abundance of, optimal rearing habitat may exacerbate juvenile sucker mortality or restrict juvenile growth or development.

Summer age-0 sucker habitat use and distribution has been studied extensively, but many uncertainties remain about age-1 and older juvenile habitat use, distribution, and movement patterns within Upper Klamath Lake. We designed a study to examine seasonal changes in distribution of age-1 suckers in Upper Klamath Lake as they relate to depth and water quality. In this document, which meets our annual data summary and reporting obligations, we discuss the results of our second annual spring and summer sampling effort.

Catch data collected in 2007 and 2008 indicate seasonal changes in age- 1 and older juvenile sucker habitat use coincident with changes in water quality, which were previously undocumented. In both years during April and May, age-1 and older juvenile suckers were found in shallow water environments. Then, as water temperatures began to warm throughout Upper Klamath Lake in June, age-1 and older juvenile suckers primarily were captured along the western shore in some of the deepest available environments. Following a dramatic decrease in dissolved oxygen concentrations in Eagle Ridge Trench, juvenile suckers were no longer found along the western shore but were captured throughout the rest of Upper Klamath Lake. When dissolved oxygen concentrations were 4 milligrams per liter or greater along the western shore, juvenile sucker captures were again concentrated in that area. Although this pattern indicates that low dissolved oxygen concentration or another related waterquality limitation may force juvenile suckers to leave the western shore, it is unclear as to why age-1 and older juveniles might be attracted to the area in the first place. Understanding this apparent behavior could be important to managing habitat for these species. 
In this data summary, we also describe the distribution of catches of age- 0 suckers and other fishes in Upper Klamath Lake. These data corroborate previous studies that describe age-0 sucker habitat as shallow relative to depths available in Upper Klamath Lake. In this study, we did not seek, nor find additional clarification on age-0 sucker habitat use and distribution in Upper Klamath Lake. Our brief description of the distribution and abundance of all other fish species caught provides a context in which to assess the rarity of juvenile suckers within the fish community of Upper Klamath Lake.

\section{Project Introduction and Background}

Rapid declines in catch rates for juvenile endangered Lost River sucker (Deltistes luxatus) and shortnose sucker (Chasmistes brevirostris) and a lack of substantial recruitment into adult sucker populations in recent years indicates that these sucker populations experience high mortality between their first summer and first spawn. Low relative catch rates of age-1 compared to age-0 Lost River and shortnose suckers in Upper Klamath Lake, Oregon, may be due to sampling the wrong environments, poor detection probability, the true rarity of this age class, or a combination of these. Dramatic declines in age-0 catch rates between late August and early September each year combined with extremely low catches of age-1 or older suckers in Upper Klamath Lake, Oregon (Hendrixson and others, 2007; Terwilliger and others, 2008), indicate that these species experience unusually high mortality within their first year of life (National Research Council, 2004). This high apparent mortality may be exacerbated by a lack of optimal over-wintering habitat, diminishing rearing habitat, declining summer water quality, or a combination of these. The causes and rates of mortality cannot be adequately assessed, however, without first examining age-dependent catchability and seasonal dynamics in the distribution and habitat use of age- 0 and age- 1 suckers. This is because most methods of assessing mortality depend on the assumptions that all age classes of fish are equally likely to be captured and that a representative sample of individuals from a homogenously distributed population can be obtained (Hilborn and Walters, 1992).

One way to examine the value of lake environments as over-wintering habitat is to examine the spatial distribution of post-winter catch rates. Lake environments producing high catch rates of surviving juvenile suckers are assumed to provide better winter habitat. A limited amount of available data indicates post wintering (spring) and early summer distributions of juvenile suckers are concentrated in tributary mouths and near springs. Between April 21 and May 11, 1992, Markle and Simon (1993) caught a relatively high number of age-1 and older subadult suckers (76) in overnight trap nets set in tributaries at the northern end of Upper Klamath Lake. However, they caught few in trap nets set off-shore during the same time period (4) or in off-shore otter trawls conducted each spring since 1996 (fewer than 20 between 1996 and 2006; Simon and others, 2000a, 2000b; Simon and Markle, 2001, 2002, 2006; Terwilliger and others, 2008). U.S. Geological Survey (USGS) employees also caught age-1 suckers near the mouth of the Williamson River and at the springs along the eastern shore in early July between 2004 and 2006 (Hendrixson and others, 2007; Burdick and others, 2007). Age-1 and older suckers may be selecting springs and tributaries because of their unique water chemistry, warmer winter temperatures, or winter productivity, but none of these hypotheses have been tested.

Although summer age-0 sucker habitat use and distribution is fairly well understood in Upper Klamath Lake (VanderKooi and Buelow, 2003; Terwilliger and others, 2004; VanderKooi and others, 2006; Hendrixson and others, 2007; Burdick and others, 2007, 2008), almost no information exists on the habitat use and distribution of age-1 suckers. Age-0 suckers use near-shore and off-shore lake environments with and without emergent vegetation (Hendrixson and others, 2007). They also have been captured over a variety of substrates including mud and sand (Buettner and Scoppettone, 1990; 
Hendrixson and others, 2007) as well as cobble and gravel (Terwilliger and others, 2004; Hendrixson and others, 2007). Between 2001 and 2006, age-1 and older juvenile suckers were sporadically caught in both open water and environments dominated by Schoenoplectus acutus (VanderKooi and Buelow, 2003; VanderKooi and others, 2006; Hendrixson and others, 2007). Catch rates between 2001 and 2006 tended to be slightly greater within $200 \mathrm{~m}$ of shore than in nets set 400 or $600 \mathrm{~m}$ from shore $(\mathrm{n}=24$; U.S. Geological Survey, unpub. data; 2001-06). Near-shore sampling from 2004 to 2006 indicated that age-1 and older juvenile suckers were approximately equally dispersed in the northern (56 percent, $n=14$ ) and southern (44 percent, $n=11$ ) ends of the lake (U.S. Geological Survey, unpub. data, 2001-06). Near-shore to off-shore trap net transect surveys at five locations along the eastern shore of Upper Klamath Lake between 2002 and 2006 indicated age-1 suckers were concentrated around Hagelstein Park and the mouth of the Williamson River in early July (VanderKooi and Buelow, 2003; Hendrixson and others, 2007; VanderKooi and others, 2007). However, all these habitat use and distribution trends are based on very small sample sizes and therefore habitat preferences are uncertain.

The effects of water quality on age- 0 and age- 1 sucker distribution are not well understood, but may be a key component in understanding seasonal changes in habitat use. Martin and Saiki (1999) determined that dissolved oxygen (DO) concentrations are the most critical factor affecting juvenile Lost River sucker survival in Upper Klamath Lake. This may help explain the association between high concentrations of DO and juvenile sucker catch rates (Buettner and Scoppettone, 1990; Terwilliger and others, 2004). Lethal pH levels and concentrations of DO for juvenile Lost River and shortnose suckers (Saiki and others, 1999) occur locally in areas of Upper Klamath Lake almost every year (Terwilliger and others, 2004; Wood and others, 2006) and sublethal levels (Loftus, 2001) are common throughout the lake in July and August (Lindenberg and others, 2008). DO concentrations and pH levels in Upper Klamath Lake are positively correlated as a result of increased photosynthetic activity by massive blooms of the cyanobacterium Aphanizomenon flos-aquae (Lindenberg and others, 2008). Therefore, environments with both low $\mathrm{pH}$ and high DO concentrations are not normally available during bloom cycles, forcing juvenile suckers to occupy habitats with one or the other. For example, Burdick and others (2008) reported slightly higher occupancy rates by age-0 suckers at sites with both high daily mean $\mathrm{pH}$ and DO concentrations rather than at sites with low or moderate daily mean $\mathrm{pH}$ and high DO concentrations.

Differential detection of a species among environments or age classes, often unaccounted for in fisheries research, can lead to biased conclusions about habitat use (MacKenzie, 2005; MacKenzie and others, 2006) or mortality rates. For example, studies that assessed capture efficiency for amphibians and stream-dwelling salmonids determined that gear bias varied among sampling sites and sampling occasions and was dependent on environmental variables (Bailey and others, 2004; Peterson and others, 2004; Weir and others, 2005). The probability of detecting age-0 suckers in fyke nets set near-shore in less than $3 \mathrm{~m}$ of water is negatively correlated with depth and positively associated with catch rates in mid to late summer (Burdick and others, 2008). Failing to account for these variations in detection would cause erroneously low estimates of habitat use in early summer and deeper water.

When catch per unit effort approaches are used to assess habitat use, schooling behavior may cause imprecise or biased estimates. Catch per unit effort within identical habitats can range dramatically when fish school. This variability will result in imprecise estimates of habitat use. High variability in catch rates due to schooling combined with small sample sizes also may result in biased estimates. 
In 2008, we continued research on juvenile sucker habitat use began by the USGS in 2001. Age-0 catch rates in 2006 were more than an order of magnitude greater than in previous years, which prompted us to refocus our research from age-0 to age-1 sucker distributions and habitat use in 2007. We took a seasonal approach to our research that included low intensity spring and fall sampling and intensive summer sampling components. Spring and fall sampling was designed to gather basic data on the distribution of age- 1 suckers as they emerge from winter in shoreline environments and age-0 suckers as they prepare for winter throughout Upper Klamath Lake. Whereas, summer sampling was designed to quantitatively estimate the influence of environmental variables on age- 0 and age- 1 sucker distribution throughout Upper Klamath Lake, while accounting for imperfect detection. In addition to these two components, in 2007, we began a project to evaluate passive integrated transponder (PIT) tag loss and the effects of PIT tags on survival of age-1 Lost River suckers. We continued this project in 2008 by tagging a few additional age- 1 suckers in an attempt to increase our sample size and improve the validity of our conclusions.

Preliminary results from 2007 indicated that although age-0 suckers were most likely to use shallow (1 to $3 \mathrm{~m}$ ) water widely available in Upper Klamath Lake throughout the summer, age-1 suckers were most likely to use deep ( 4 to $5 \mathrm{~m}$ ) water environments in the summer, which are diminished at lower lake-surface elevations. This depth selection for age- 1 suckers is similar to that of adult suckers, which are known to concentrate at water depths $3 \mathrm{~m}$ or greater (Banish and others, 2009).

In 2008, we continued research focused on age- 1 and older juvenile sucker habitat use and distribution begun in 2007 and continued research on seasonal dynamics in habitat use by age-0 sucker begun in 2001. Continued sampling in 2008 allowed us to track the relatively strong 2006 cohort into their second year of life and examine changes in habitat use as this year-class ages. Our specific objectives included:

Objective 1: Qualitatively examine spring (early May to mid-June) and late summer (midAugust to early September) spatial distribution of age-0, age-1, and older juvenile shortnose and Lost River suckers in Upper Klamath Lake, Oregon.

Objective 2: Quantitatively estimate mid-summer (mid-June to late July) detection and habitat use probabilities in Upper Klamath Lake, Oregon, across a range of available depths for age-0, age-1, and older juvenile shortnose and Lost River suckers.

Objective 3: Examine co-occurrence patterns among sucker and non-sucker species in Upper Klamath Lake, Oregon.

Objective 4: Qualitatively examine the effects of summer water quality on habitat use by age0, age-1, and older juvenile shortnose and Lost River suckers.

We set both annual and long-term goals for reporting our results and will produce annual data summaries, as well as comprehensive reports deliverable every 3 years. Annual data summaries, like this one, are peer reviewed open-file reports intended to make data quickly available to our partners and other resource management agencies. Whereas, comprehensive reports will be peer reviewed documents that contain analysis and interpretation of these data. 
Our 2007 and 2008 summer sampling protocol was designed to quantitatively estimate detection probability, distribution, and habitat use of age-0 and age- 1 suckers throughout Upper Klamath Lake.

Our approach allowed us to evaluate the importance of water depth, water quality, and season in relation to habitat use and detection probability of age- 0 and age- 1 suckers. The information we present in this data summary and future reports regarding summer distribution and habitat use for age-0 and age-1 suckers will help improve sampling design for future research and assist in management of water resources, endangered species, and restoration efforts.

\section{Study Area}

Our study area is located in the Upper Klamath Basin of southern Oregon and northern California. The project area is located entirely within Upper Klamath Lake, presently the largest lake in the basin (fig. 1). Upper Klamath Lake, which covers approximately $271 \mathrm{~km}^{2}$ (67,000 acres) at full pool, is uniformly shallow, averaging less than $2.13 \mathrm{~m}$ in depth at mean summer lake surface elevation except in a trench along the western shore, which has depths between 6.40 and $9.45 \mathrm{~m}$ (National Research Council, 2004). Before the construction of the Link River Dam in 1921, the surface elevation of Upper Klamath Lake only varied by about $1 \mathrm{~m}$ over the entire year (National Research Council, 2004). The construction of the dam allowed surface elevation to be drawn down by an additional $1 \mathrm{~m}$ (National Research Council, 2004).

Poor water quality in Upper Klamath Lake is associated with the death of massive blooms of the blue-green cyanobacterium A. flos-aquae. Spatial patterns in water quality change with weather conditions, including wind and water temperature (Wood and others, 2008). During the spring, DO concentrations generally are suitable for juvenile suckers throughout Upper Klamath Lake (Lindenberg and others, 2008). As air and water temperatures increase in the summer, A. flos-aquae produces massive blooms (Lindenberg and others, 2008). Then, between mid-July to early August each year, chlorophyll a concentrations plummet, indicating a massive algal die-off event. The large-scale cell senescence that occurs during such events is associated with rapid decreases in daily median $\mathrm{pH}$ and DO concentrations (Lindenberg and others, 2008). This phenomenon, which is referred to locally as the "bloom-crash", usually occurs first and is the most severe in Eagle Ridge Trench along the western shore of Upper Klamath Lake (fig. 1) (Lindenberg and others, 2008). DO concentrations are lowest in the deepest part of the lake where they can be less than $4 \mathrm{mg} / \mathrm{L}$ for several days (Lindenberg and others, 2008). Pelican Bay, located along the northwestern shore of Upper Klamath Lake (fig. 1), is recharged by groundwater, remains relatively free of algal blooms, and provides refuge habitat for adult suckers during periods of low DO concentrations in the lake (Banish and others, 2009). 


\section{Methods}

\section{Approach}

We used a random stratified sampling design to address objectives one through four, to collect age- 1 suckers that could be tagged, and to examine age- 0 and age- 1 sucker seasonal habitat use in Upper Klamath Lake. We sampled six strata, which included near-shore and off-shore strata in each of three areas of Upper Klamath Lake: (1) north and west of Eagle Point and the mouth of the Williamson River, (2) south and east of Eagle Point and the mouth of the Williamson River and north of Sesti Tgawallis Point and Hagelstein Park, and (3) south of Hagelstein Park and Sesti Tgawallis Point including Howard Bay (fig. 1). Sites available for sampling were conceptualized as $2,500-\mathrm{m}^{2}$ cells covering the entire lake. Available near-shore sites consisted of two concentric $50 \times 50$-m rectangular bands running along the entire shoreline. Off-shore sites were considered hexagonal cells at least $100 \mathrm{~m}$ from shore. Sampling in Upper Klamath Lake coincided with sampling in and near the Williamson River Delta conducted under agreement 04AA204032 with the Bureau of Reclamation and reported in Burdick and others (2009b) a separate USGS open file report.

We divided the sampling period into three seasons; May 5 through June 19 (spring), June 23 through July 31 (mid-summer), and August 4 through September 11 (late-summer). The same sites were visited in the mid- and late-summer periods in both 2007 and 2008 to facilitate inter-annual comparisons in catch rates for the 2006 cohort (objective 1). Seasonal sample allocation was designed to capture age1 and older juvenile suckers in the spring, the peak of age- 0 sucker abundance in the mid-summer period, and the decline of age- 0 sucker abundance in the late summer period. Due to a reduced allocation of effort in the spring and late summer sampling periods, we primarily sampled near-shore strata. In the mid-summer period, we sampled in both near and off-shore strata. We delineated these time periods based on historic catch data for age-0 and age-1 suckers (VanderKooi and others, 2006; Hendrixson and others, 2007; Burdick and others, 2007, 2009a), a technique that will allow us to address objective 2 .

We set three replicate nets at each site during the mid-summer sampling season and a subset of sites in the spring and late summer seasons to meet the requirements of occupancy models in estimating detection and unbiased habitat use probabilities (objective 2). When three nets were set at one site, the mouth openings were arranged to be about 120 degrees to each other to avoid interference among nets.

\section{Sample Collection}

Juvenile fish were sampled with rectangular nets with mouth dimensions of $0.609 \times 0.914 \mathrm{~m}$, a 15 -m lead, and three internal fykes. These nets were fitted with $6.4 \mathrm{~mm}$ green nylon netting. Nets were set between 1040 and 2006 hours each afternoon and pulled the next day between 0802 and 1831 hours, for a target soak time of 20 hours. Net set and pull times and the depth at both the end of the lead net and at the net mouth were recorded for each net. Lead and mouth depths for all three nets at each site were averaged for this data summary. At each site less than $3 \mathrm{~m}$ deep, we probed the bottom of the lake with a PVC pole and made an educated guess about substrate composition. The percentage of the entire site covered with vegetation and the portion of plants in each genus within a random $1 \mathrm{~m}^{2}$ sample also were recorded. 
Captured fish were identified to species or lowest practical taxonomic group and counted. For all suckers, standard length (SL) was measured and the presence of deformities and macroparasites was noted. When catches exceeded $3 \mathrm{~kg}$, a subsample was taken for all species except juvenile suckers. Prior to subsampling, the presence and absence of each species in the entire sample was recorded in four size bins (tiny < 40 mm SL, small 40-100 mm SL, medium 100-200 mm SL, and large $\geq 200 \mathrm{~mm} \mathrm{SL)} \mathrm{and}$ all suckers were measured and removed from the sample. Subsamples were taken by placing the entire sample in a large water-filled tub, thoroughly mixing the contents of the tub, and removing about 30 percent of the original sample weight using a dip net. The total number of each species except suckers in the total catch was estimated by extrapolation using the ratio of subsample weight to total weight. Subsample species composition was assumed representative of total catch. Catch per unit effort (CPUE) was calculated as fish per net rather than fish per hour for each non-sucker species because there was not a linear relation between the number of fish captured and the length of time that nets were in the water.

As a preliminary step in studying movement patterns in relation to environmental variables, healthy suckers $70 \mathrm{~mm}$ SL or longer collected during spring sampling were injected with a full duplex, $12.45 \times 2.02 \mathrm{~mm}, 0.106 \mathrm{~g}$ in air, $134.2 \mathrm{kHz}$, cylindrical passive integrated transponder (PIT) tag. Suckers that were not emaciated, had no external macroparasites, were free of deformities, and had no lesions or other wounds were considered healthy. Prior to tagging, suckers were scanned for the presence of a tag and anesthetized in a 0.02 to $0.03 \mathrm{mg} / \mathrm{L}$ solution of MS-222, which was prepared with lake water. All suckers were allowed to remain in the solution until they did not respond to probing. All taggers were trained using preserved specimens prior to tagging live fish. Between each injection, needles were sterilized with Nolvasan ${ }^{\circledR}$ disinfectant. Wounds were not closed with sutures and no antibiotics were administered.

Tagged suckers were allowed to recover in a bucket of lake water prior to being transferred to $0.21-\mathrm{m}^{3}$ net pens, where they were held overnight to assess tagging survival and tag loss. Net pens were suspended about $0.5 \mathrm{~m}$ off the substrate at the locations where fish were originally captured. Upon retrieval of the pens, sucker mortalities and tags lost were recorded before live suckers were released at their location of capture.

Approximately one out of three captured suckers $70 \mathrm{~mm}$ SL or less and one out of ten suckers 71 to $145 \mathrm{~mm}$ SL were sacrificed and preserved in 95 percent denatured ethanol for identification to species. Sacrificed suckers that were not dissected for fish health assessments associated with another research project were weighed upon returning to the laboratory. We identified juvenile suckers to species in the laboratory with a method developed by Markle and others (2005) using a combination of techniques including vertebrae enumeration, lip morphology, and gill raker counts. The estimated number of each sucker species in a catch was obtained by multiplying the species proportion in the subsample of sacrificed fish by the total number of juvenile suckers caught in the sample. We classified suckers as age-0, age-1, or older based on weekly length frequency plots.

\section{Water-Quality Data}

Water-quality data were collected separately by the USGS Oregon Water Science Center for a concurrent lake water-quality study. These data, which are publicly available through an agency web site (U.S. Geological Survey, 2009), were collected at 15 sites throughout Upper Klamath Lake. A total of 12 of these sites were located away from shore, and 3 were located within 5-10 m of shore or in littoral vegetation. At each site, YSI (model 600XLM or model 6920) continuous water-quality monitors were deployed $1 \mathrm{~m}$ off the bottom. Monitors measured DO concentration, $\mathrm{pH}$, specific conductance, and temperature once hourly between May 8 and October 14, 2008. In this report, we give 
an abbreviated summary of temperature and DO concentration data collected at three sites in order to put the spatial-temporal distributions of juvenile suckers in context (objective 4). Data from three waterquality monitoring stations were examined for this report. The Eagle Point station (USGS site EPT-L, 422559121574400) is representative of conditions in Eagle Ridge Trench. The Howard Bay station (USGS site HDB, 421933121550000) is representative of conditions in Howard Bay. The mid-north station (MDN-L; UGSS site number 422622122004000) is representative of conditions east of Ball Bay, Shoalwater Bay, Howard Bay, and Eagle Ridge Trench, and north of Buck Island (fig. 1; U.S.

Geological Survey, 2009).

\section{Summarizing and Reporting Data}

Juvenile sucker catch data were summarized to describe spatial-temporal patterns in distribution and relative abundance, species composition, and age and length structure in the sampled population. We calculated catch rates to describe the magnitude of catches and naïve occupancy to describe the extent of spatial distribution. Catch rates were calculated as fish per net rather than fish per hour because we were not able to determine any relation between the number of fish and the number of hours a net was set. Naïve occupancy was calculated as the percentage of sites at which we caught at least one sucker in a category of interest. This value is known as the naïve occupancy rate because it has not been adjusted for a reduced probability of detection.

We summarized the frequency of parasites and deformities, calculated the relative weight for each sacrificed age- 0 sucker that was weighed, and described the size of juvenile suckers in each age class to describe general condition of juvenile suckers in our catches. Relative weight $\left(W_{r}\right)$ was calculated as the weight for each age-0 sucker divided by the predicted weight, based on species specific length-weight relationships established for age-0 suckers caught in 2006 (Burdick and others, 2007), and multiplied by 100 (Anderson and Neumann, 1996). For sacrificed suckers that exhibited characteristics intermediate of Lost River, shortnose, and Klamath largescale suckers (Catostomus snyderi), we averaged shape parameters from established length-weight equations of Lost River and shortnose suckers. Values of $W_{r}$ of 100 indicate suckers with similar length weight ratios as those collected in 2006, whereas values less than 100 indicate emaciation and values greater than 100 indicate fish were rotund relative to the typical sucker caught in 2006 (Anderson and Neumann, 1996).

Catch data for other species was summarized to describe timing and distribution of individual species, and diversity and structure of communities. To assist in describing community structure, we calculated species richness and the Shannon-Wiener index of diversity (McCune and Grace, 2002) for each sample. The Shannon-Wiener index is a way of describing the information content in a given community and describes the evenness among species. A high Shannon-Wiener index indicates more equal representation of species in a community or sample.

\section{Results of Sample Collection and Data Summary}

\section{Sampling Effort}

During 19 weeks of sampling, we set 1,434 trap nets overnight at 663 sites for a total of 29,874 hours of soak time. The duration of trap net samples ranged from 15.4 to 27.8 hours and averaged (mean \pm SE) $20.9 \pm 1.7$ hours. Seven nets failed during mid-summer sampling and their catches are not

included in this data summary. Five of the seven nets were located in the South Near-shore stratum, one was located in the North Near-shore stratum, and one was located in the North Off-shore stratum. Most 
(67 percent) sites were visited only once, although others were visited up to six times (table 1), resulting in a total of 662 site visits (table 2) in 2008. Three nets were simultaneously set at a single site on a single occasion 381 times (table 2). We subsampled five catches that weighed between 4.0 and $10.2 \mathrm{~kg}$.

\section{Summary of Water-Quality Conditions}

Overall seasonal trends in DO concentrations and temperature were similar among all three selected water-quality monitoring stations. Daily median values and diel swings in these variables, however, were different among the stations. Between May 7, the first day that water-quality monitors were recording in 2008, and June 22, DO concentrations generally varied by less than $2 \mathrm{mg} / \mathrm{L}$ at all three water-quality monitoring stations. The only exceptions were 5 days in May at Eagle Point, where erratic diel fluctuations in DO were recorded (fig. 2). Water temperatures increased at all selected waterquality sites between the weeks of June 8 and June 29 (fig. 2). The least diel variation in water temperature was recorded at Eagle Point, slightly more was recorded at Mid-North, and the greatest diel variation was recorded in Howard Bay (fig. 2). Beginning the week of June 22, diel swings in DO concentrations increased at all three sites, but were the most pronounced in Howard Bay (fig. 2). Coincident with increasing temperatures, DO concentrations began to decrease at both the Mid-North and Eagle Point sites and continued to decrease until the week of July 13 (fig. 2). DO concentrations remained low at both Eagle Point and Mid-North until the week of August 17 (fig. 2). In Howard Bay, DO concentrations decreased to a seasonal low the week of August 17, before increasing beginning the week of August 24 (fig. 2). At the Mid-North site, median daily DO concentrations only decreased to less than $4 \mathrm{mg} / \mathrm{L}$ on 3 days between July 13 and August 16 (fig. 2). In contrast, median daily DO concentrations decreased to less than $4 \mathrm{mg} / \mathrm{L}$ on 30 days, less than $2 \mathrm{mg} / \mathrm{L}$ on 14 days, and less than 0.5 $\mathrm{mg} / \mathrm{L}$ on 7 days during the same time period at Eagle Point (fig. 2).

\section{Age and Species Composition of Juvenile Suckers}

We captured 358 suckers in Upper Klamath Lake, Oregon, between May 7 and September 12, 2008. Based on weekly length frequency distributions, we estimate that about 71 percent of these suckers were age-0, 18 percent were age-1, and 11 percent were age-2. We sacrificed 122 age-0 suckers, 9 age- 1 suckers, and 1 age- 2 sucker for identification to species, histology, or collection of tissues for a related fish health study (Burdick and others, 2009a). Sacrificed age-0 suckers were nearly equally divided between shortnose suckers (37 percent) and Lost River suckers (36 percent), with the remainder identified as having intermediate characteristics of Lost River, shortnose, and Klamath largescale suckers (21 percent). A much smaller portion was identified as Klamath largescale suckers (6 percent). Three of the nine sacrificed age-1 suckers were identified as shortnose suckers, two were identified as Lost River suckers, and four were identified as having intermediate characteristics of Lost River, shortnose, or Klamath largescale suckers.

\section{Spatial-Temporal Patterns in Age-1 and Age-2 Sucker Catches}

When examined independently of spatial patterns, there were no apparent temporal patterns in catches of age-1 suckers throughout Upper Klamath Lake in 2008. Mean ( \pm SE) weekly age-1 sucker catch rates (suckers per net) were highly variable and ranged from a high of $0.13 \pm 0.13$ during the week of June 1 to a low of 0 during 5 separate weeks between May 11 and August 31 (fig. 3). The percentage of sites sampled each week at which at least one age- 1 sucker was detected ranged from 0 to 20, but the median weekly detection rate was only 5 percent. 
Patterns in spring spatial distributions of juvenile suckers were difficult to detect, given that we only captured nine age- 1 and three age-2 suckers between May 5 and June 19, 2008. Age-1 suckers were only captured in two stratum with catch rates slightly higher in the South Near-shore stratum $(0.12$ suckers per net) than in the North Near-shore stratum (0.05 suckers per net). A single age-2 sucker was captured in each near-shore strata during this same time period, resulting in nearly equal catch per unit effort in each of these strata (table 3). Spring age-1 and age-2 sucker catches occurred at water depths between 1.6 and $6.2 \mathrm{~m}$. Median depth at sites where suckers were caught $(2.9 \mathrm{~m})$ was only slightly less than median depth at all sites sampled (3.6). Three age-1 suckers were administered a PIT tag, held overnight, and released the next day alive with the PIT tag retained. No juvenile suckers, however, were recaptured with a PIT tag during this study.

There were no clear differences in mean weekly catch rates or naïve occupancy estimates for age-1 suckers between near-shore and off-shore sites (fig. 4). If temporal patterns occurred in catch rates or naïve occupancy within near and off-shore strata for this age class, we also were unable to detect them (fig. 4). Our off-shore sampling, however, was very limited between May 4 and June 21 and nonexistent after August 9, limiting our ability to detect temporal trends.

The spatial distribution of age- 1 and age-2 sucker catches throughout Upper Klamath Lake changed between June 22 and August 3, our most intensive sampling period and the only period of substantial off-shore sampling. We caught a few age- 1 and age-2 suckers around the perimeter of Upper Klamath Lake during the week of June 22 (fig. 5), but not necessarily within $100 \mathrm{~m}$ of shore (fig. 4). Our greatest catch rates during that week occurred near the mouth of the Williamson River and near Hagelstein Park (fig. 5). Age-1 suckers continued to be caught in both near and off-shore environments during the week of June 29, apparently randomly distributed around the perimeter of the lake. However, age-2 suckers, were only caught within $100 \mathrm{~m}$ of the western shore (figs. 4 and 5). The following week (week of July 6), the spatial pattern in age-1 sucker catches was similar to age-2 sucker catches, occurring primarily on the western shoreline. Then, just as abruptly as these two age classes appeared in our western shore samples, the spatial catch pattern returned to a more random lake wide distribution between July 13 and July 26 (fig. 5). In the final week of our mid-summer intensive sampling period (July 27 to August 3), we did not catch any age-1 or age-2 suckers.

Temporal patterns in the depths at which age- 1 and age- 2 suckers were captured tell a similar story about changing distributions. The median depth of age- 1 suckers gradually increased between the weeks of June 15 and July 6 (fig. 6) coincident with an increase in catches of this age class along the western shore of Upper Klamath Lake. The weekly median depth of age-2 sucker catches became shallower between the weeks of June 29 and July 20.

In the 6 week late-summer sampling period (August 3 to September 13), our sampling effort focused solely on near-shore habitats. We did not catch any age-1 or age-2 suckers during the weeks of August 3 and August 31. In the other 4 weeks, catches of age- 1 and age- 2 suckers all occurred along the western shoreline with the exception of one catch near Buck Island (fig. 5).

\section{Spatial-Temporal Patterns in Age-0 Sucker Catches}

Catch rates for age-0 suckers exhibited an almost bi-modal distribution across weeks. This sucker age class began recruiting to our nets during the week of July 6 between 41 and 49 mm SL (fig. 7). The mean weekly catch rate increased to a moderately high level during the week of July 27, 1 week after shortnose suckers were first detected in our samples (fig. 8). This was followed by a slight decrease in mean weekly catch rates during the weeks of August 3 and August 10 (fig. 8). Mean weekly catch rates increased steadily throughout August (fig. 8) and then declined slightly during our last week of sampling (September 7; fig. 8). 
The weekly naïve occupancy rate (percentage of nets that caught at least one sucker) ranged from 1 to 19 percent and also followed an almost bi-modal distribution over the season (fig. 8). After initially low catches in the first part of July, the weekly naïve occupancy rate increased to a seasonal high of 19 percent during the week of July 27. This rate decreased during the weeks of August 3 and August 10 before climbing back up to a rate of 17 percent the week of August 24. The naïve occupancy rate then decreased by 1 percent during the weeks of August 31 and September 7.

Age-0 Lost River suckers were collected slightly earlier than shortnose suckers. Age-0 Lost River suckers were first detected in our samples the week of July 6 but age- 0 shortnose suckers were not detected until the week of July 20 (fig. 8). We recorded a pulse of moderately high catch rates for Lost River suckers the week of August 3 and for shortnose suckers the week of August 10. Species specific catch rates, as estimated through extrapolation from sacrificed fish, peaked during the week of August 24 for both Lost River and shortnose suckers.

Age-0 suckers were first detected in both southern strata on the week of July 6 (figs. 9 and 10), 2 weeks prior to being detected in either the central or northern off-shore strata (fig. 10), and 3 weeks prior to being detected in the central or northern near-shore strata (fig. 9). For the first 3 weeks that age0 suckers were detected, however, catch rates and naïve occupancy estimates were low compared to later in the summer (figs. 9 and 10). In the southern and central near-shore strata, mean weekly catch rates and estimates of naïve occupancy did not seem to follow any temporal pattern (fig. 9). In contrast, catch rates and estimates of naïve occupancy in the northern near-shore stratum increased steadily throughout August (fig. 9) and then declined slightly during the last week of sampling (September 7).

Mean weekly catch rates and naïve occupancy rates for age- 0 suckers were slightly higher in offshore than in near-shore strata between the weeks of July 6 and July 27 (figs. 9 and 10). Between the weeks of July 20 and July 27, catch rates for these suckers increased in all three off-shore strata. We were unable to determine if these trends continued, however, because we stopped sampling off-shore on August 1.

When combined over all 12 weeks that age-0 suckers were detected, mean catch rates were greatest in nets set in less than $1 \mathrm{~m}$ of water and lowest in nets set at depths of $6 \mathrm{~m}$ or greater (fig. 11). This pattern was not substantially different when Lost River suckers were examined separately from shortnose suckers (fig. 11). There was, however, a slight temporal pattern in the depths at which suckers were caught. Median depth of age-0 sucker catches was greatest during the weeks of July 6 and August 31. In between these 2 weeks, the median depth at which age- 0 suckers were caught was slightly shallower (fig. 7).

\section{Juvenile Sucker Condition}

Deformed opercles were commonly observed on age-0 Lost River and shortnose suckers, but were rarely observed on age- 1 suckers. For age-0 suckers of all species combined, 18 percent had at least one deformed opercle and 10 percent had both opercles deformed. These percentages were not substantially different between Lost River and shortnose suckers. A total of 15 percent of sacrificed age0 Lost River suckers had at least one deformed opercle and 20 percent of these had both opercles deformed. For sacrificed age-0 shortnose suckers, 6 percent had at least one deformed opercle, and 22 percent of these had two deformed opercles. In contrast, only one of the nine (11 percent) sacrificed age-0 Klamath largescale suckers had a single deformed opercle. Only 9 percent of age- 1 suckers had at least one deformed opercle, only 3 percent had two deformed opercles, and only one age- 2 sucker (3 percent) had a single deformed opercle. 
Parasitic anchorworms (Lernaea spp.) were rare on suckers collected from Upper Klamath Lake in 2008. Anchorworms were found on a low percentage of sacrificed age-0 Lost River suckers (4 percent), and were not found on any sacrificed age- 0 shortnose suckers. Anchorworms were attached to only 1 percent of age- 1 suckers and 17 percent of age- 2 suckers. The low abundance of anchorworms, never more than one per fish, suggests these parasites were not a major hindrance to the health of these fish.

Length and weight data indicate that age-0 suckers grew and were in relatively good condition. When weekly sample sizes were reasonably large $(n>7)$, median standard length of age- 0 suckers caught in our nets generally increased each week in the north, south, and central areas of the lake. Exceptions to this pattern were (1) a decrease in median standard length between the weeks of August 17 and August 24 in the central area and (2) a decrease in median standard length between the weeks of August 31 and September 7 in the central and northern strata (fig. 12). Only 26 age-0 suckers were weighed prior to dissection, and therefore suitable for inclusion in the relative weight assessment. The mean $\left( \pm\right.$ SE) relative weight $\left(W_{r}\right)$ for age-0 suckers caught in Upper Klamath Lake in 2008 was $114.7 \pm$ 7.2, indicating that these fish typically were heavier, given their length, than the same age fish caught in near-shore habitat in 2006.

\section{Summary of Bycatch}

We captured a total of 14 non-sucker fish species in our trap net sampling between May 4 and September 14. Our catches were dominated by tui chub (Gila bicolor), blue chub (Gila coerulea), and fathead minnow (Pimephales promelas). Yellow perch (Perca flavescens), Klamath Lake sculpin (Cottus princeps), and Upper Klamath marbled sculpin (Cottus klamathensis klamathensis) also were abundant in our catches (fig. 13). Sunfish (Lepomis spp.), lamprey (Lampetra spp.), brown bullhead (Ameiurus nebulosus), and slender sculpin (Cottus tenuis) were less common in our catches (fig. 13). We also caught three largemouth bass (Micropterus salmoides), one redband trout (Oncorhynchus newberii), and one speckled dace (Rhinichthys osculus). Species richness ranged from zero to ten among sites and averaged (mean \pm SE) $5.3 \pm 0.07$.

Species composition generally was similar among all parts of the lake with some minor variations. Although fathead minnow were common in all parts of the lake, the highest catch densities were reported during the week of August 10 in the northern strata (fig. 13). Catch rates for yellow perch were slightly higher in the northern strata than in other strata, although catch rates for Upper Klamath Lake sculpin were slightly greater in the central and southern strata. Brown bullhead were caught in all six strata; their catch rates were highest at near-shore sites.

\section{Discussion}

\section{Distribution and Movement of Age-1 and Older Juvenile Suckers}

Low overall catch rates for age-1 suckers, such as was reported in this data summary for the spring and summer of 2008, are common in Upper Klamath Lake. Markle and Simon (1993) set 27 overnight trap nets (904 soak hours) during April and May 1992 and captured 76 juvenile suckers in tributaries of Upper Klamath Lake, but only 4 in the lake itself. They attributed small relative catches of suckers, when compared to total catch size, to their sedentary nature, which contrasts with the active blue and tui chub. Differences in detectability among species are certainly a major factor in estimating abundance from catch rates, but consistently low catches of young suckers in both passive and active gears indicate that the abundance of these fishes may actually be low in Upper Klamath Lake. From 
1996 to 2007, Simon and Markle (2008) pulled otter trawls in off-shore areas of Upper Klamath Lake between April and May. In this long-term monitoring program, seasonal catch rates never exceeded 0.15 suckers per 20-m tow, providing further evidence that spring abundance of age-1 suckers within Upper Klamath Lake commonly is low.

The overall catch rate for age-1 suckers in our study was lower in 2008 (0.04 fish per net) than in 2007 when the same sampling protocol was used (0.27 fish per net; Burdick and others, 2009a). Given that catch rates for age-0 suckers were about 66 times greater in 2006 than in 2007 (Burdick and others, 2007, 2009a), it is not surprising that age-1 catch rates were considerably higher in 2007 than in 2008. The fact that the difference in catch rates for these two cohorts was greater when they were compared in their first year of life than when they were compared in their second year of life, however, suggests that either mortality was not constant between 2007 and 2008 for the same age class or that catch per unit effort is a poor indicator of year class strength. Additionally, the relatively high portion of suckers judged to be age-2 (11 percent), given their size, is further evidence that the 2006 cohort is persisting in the population.

One of the most interesting results of the 2008 data collection was the apparent movement toward, then away from, the western shore of Upper Klamath Lake first by age-2, and subsequently age1 suckers. This same pattern was observed for age-1 suckers in 2007 (Burdick and others, 2008). Because we did not recapture any marked fish, however, temporal changes in catch rates may simply indicate spatial changes in detection probability or relative abundance instead of movement. Nonetheless, given the strength of the pattern over 2 years, movement appears to be a likely explanation for the pattern we observed.

The apparent departure of age- 1 and age-2 suckers from the western shore of Upper Klamath Lake around July 12, 2008, coincided with the decrease in mean daily DO concentrations at Eagle Point (fig. 2). It was unclear, however, why these fish congregated along the western shore beginning the week of June 29 or why they appeared to return to this area after DO concentrations in Eagle Ridge Trench began to increase the week of August 17 (fig. 2). Determining what attracts age-1 and age-2 suckers to the western shore of Upper Klamath Lake could help identify which habitat characteristics are most important to preserve, restore, or create to benefit these age classes of suckers.

The environment along the western shore of Upper Klamath Lake is somewhat distinct from the rest of the lake, which allows us to suggest several possible hypotheses about why these young suckers may be attracted to that area. The western shore has some of the deepest environments available in the lake (fig. 1). When the entire sampling season was considered, age-1 and older juvenile sucker catch rates were maximized in 6-7 m of water in 2008 (fig. 11) and in $4.4 \mathrm{~m}$ of water in 2007 (Burdick and others, 2008). These depth ranges are consistent with depth selection by adult Lost River and shortnose suckers, which primarily use areas greater than 3 m deep (Banish and others, 2009). Therefore, age-1 and older juvenile suckers may be selecting deeper water. During their residency along the western shore of the lake, however, a portion of age- 1 and age- 2 suckers were caught in the shallower water of Ball, Shoalwater, and Howard bays, indicating that depth may not have been the only attractive feature of the western shore during this two week period.

Age-1 and age-2 suckers may be congregating on the western shore of Upper Klamath Lake to take advantage of the plentiful prey found in this area. Age-1 and age-2 suckers probably have a diet similar to age-0 suckers larger than about $30 \mathrm{~mm}$ standard length, which feed primarily on larval chironomids, chydorids, and ostracods (Markle and Clauson, 2006). Although these taxa are seasonally abundant in Upper Klamath Lake (J. Carter, U.S. Geological Survey, written commun., 2009), all species may not contain the same nutritional value or be preyed upon equally by juvenile suckers. Benthic invertebrate species assemblages appear to differ between Eagle Point, the entrance to Ball Bay, 
and the north-central and northeastern part of Upper Klamath Lake (J. Carter, U.S. Geological Survey, written commun., 2009). For example, Eagle Point has higher densities of benthic invertebrates than other parts of northern Upper Klamath Lake (J. Carter, U.S. Geological Survey, written commun., 2009). In addition, although Chironomus larvae are found throughout northern Upper Klamath Lake, the two Chironomus species with the largest larvae are much more common at Eagle Point than in other areas (J. Carter, U.S. Geological Survey, written commun., 2009). The entrance to Ball Bay and Eagle Point also differ from more easterly parts of northern Upper Klamath Lake by having relatively high densities of tubificid oligochaetes (J. Carter, U.S. Geological Survey, written commun., 2009). Although the oligochaetes are not known to be a substantial part of juvenile sucker diets, because of their lack of hard parts they may be rapidly digested and therefore unidentifiable in stomach analysis.

\section{Distribution of Age- 0 Suckers}

Shallow water was the most distinguishing characteristic of age-0 sucker habitat use in Upper Klamath Lake. In 2008, our catch rates for age-0 suckers were greatest in less than $1 \mathrm{~m}$ of water, which is shallower than we reported in 2007 when summer habitat use was maximized at $2.4 \mathrm{~m}$ deep (Burdick and others, 2008). This corroborates other research that report water as shallow as $0.5 \mathrm{~m}$ as being one of the most distinguishing characteristics of age-0 sucker habitat use (Buettner and Scoppettone, 1990).

Our age-0 sucker catch rates between June 22 and August 2 were not substantially different between near- and off-shore environments. Due to our sample design, which lacked off-shore sites before June 22 or after August 2, we were unable to examine temporal changes between near- and offshore habitat use. The frequent use of both off-shore and near-shore habitats by age- 0 suckers also was reported by Hendrixson and others (2007), who sampled using trap nets set as far as $600 \mathrm{~m}$ from shore.

\section{Juvenile Sucker Condition}

Juvenile suckers generally appeared to be in good condition with the exception of 25 percent of age- 0,9 percent of age- 1 , and 2 percent of age- 2 suckers that had at least one deformed opercle. These rates of opercle deformity were much greater than rates reported for Lost River sucker (4.7 percent) and shortnose sucker (1.4-3.1 percent) collected in 1993 and of a similar size to our age-0 suckers (Plunkett and Snyder-Conn, U.S. Fish and Wildlife Service, written commun., 2000). Numerous other deformities have been observed for these species (Plunkett and Snyder-Conn, U.S. Fish and Wildlife Service, written commun., 2000), but we did not observe deformities other than on opercula in x-rays or external examination of the fish we collected.

Opercle deformities that expose the gill filaments, such as those observed on age- 0 suckers in 2008, are a common phenomenon in hatchery-raised fish but are less prevalent in fish collected from natural environments (Beraldo and others, 2003). This deformity is considered to be non-lethal for hatchery-raised fish (Beraldo and others, 2003), but may lower resistance to oxygen stress and predispose fish to infections by bacteria, parasites, and fungi (Galeotti and others, 2000; Beraldo and others, 2003). The cause of this deformity could be due to inbreeding (Winemiller and Taylor, 1982; Tringali and others, 2001) or environmental conditions (Lindesjoo and others, 1994). Two potential environmental causes of this particular deformity are a lack of dietary ascorbic acid (Chávez de Martínez, 1990) or pollution (Lindesjoo and others, 1994). A lack of dietary calcium or low environmental $\mathrm{pH}$ during periods of rapid growth also may cause erratic or limited skeletal development resulting in shortened opercula (Lindesjoo and others, 1994). In Upper Klamath Lake, however, daily 
median pH is rarely less than 8.0 (Lindenberg and others, 2008). No matter what the cause, the development of a skeletal deformity, such as shortened opercula, is irreversible (Beraldo and others, 2003). Therefore, the lower incidence of this condition in older fish compared to younger fish may indicate that elevated mortality is associated with shortened opercula on suckers in Upper Klamath Lake.

The cause(s) of deformed opercles in Upper Klamath Lake suckers remains uncertain and warrants future research. An observational study that examines rates of deformities over a number of years and a large geographic range may generate candidate causes. A laboratory study, however, would be required to determine an actual relation between cause and effect.

\section{Acknowledgments}

We thank Matt Abel, Ryan Braham, Daniel Brown, Ernest Chen, Nathan Harris, and Anna Willard for help with data collection and Dave Simon (Oregon State University), and Charlie Erdman (The Nature Conservancy) for help with sucker species identification. We also thank Greta Blackwood, Amari Dolan-Caret, and Alta Scott for help with database development and management. This work was funded by the Bureau of Reclamation (Interagency Agreement 04AA204032) and the U.S. Geological Survey.

\section{References Cited}

Anderson, R.O., and Neumann, R.M., 1996, Length, weight, and associated structural indices in Murphy B.R., and Willis, D.W., eds., Fisheries Techniques, $2^{\text {nd }}$ edition: American Fisheries Society, Bethesda, Maryland.

Bailey, L.L., Simons, T.R., and Pollock, K.H., 2004, Spatial and temporal variation in detection probability of plethodon salamanders using the robust capture-recapture design: Journal of Wildlife Management, v. 68, p. 14-24.

Banish, N.P., Adams, B.J., Shivley, R.S., Mazur, M.M, Beauchamp, D.A., and Wood, T.M., 2009, Distribution and habitat associations of radio-tagged Lost River and shortnose suckers in Upper Klamath Lake, Oregon: Transactions of the American Fisheries Society, v. 138, p.153-168.

Beraldo, P., Pinosa, M., Tibaldi, E., and Canavese, B., 2003, Abnormalities of the operculum in gilthead sea bream (Sparus aurata): morphological description: Aquaculture, v. 220, p. 89-99.

Buettner, M., and Scoppettone, M.M., 1990, Life history and status of Catostomids in Upper Klamath Lake, Oregon: Oregon Department of Fish and Wildlife, Klamath Tribe, and National Fisheries Research Center, Reno, Nevada.

Burdick, S.M., Wilkens, A.X., and VanderKooi, S.P., 2007, Near-shore and off-shore habitat use by endangered, juvenile Lost River and shortnose suckers in Upper Klamath Lake, Oregon: 2006 Data Summary: U.S. Geological Survey Open-File Report 2007-1356, 30 p.

Burdick, S.M., Hendrixson, H.A., and VanderKooi, S.P., 2008, Age-0 Lost River and shortnose sucker near-shore habitat use in Upper Klamath Lake, Oregon: a patch-occupancy approach: Transactions of the American Fisheries Society, v. 137, p. 417-430.

Burdick, S.M., Anderson, G.O., and VanderKooi, S.P., 2009a, Spring and summer habitat use by endangered juvenile Lost River and shortnose suckers in Upper Klamath Lake, Oregon: 2007 Annual Report: U.S. Geological Survey Open-File Report 2009-1043, 56 p. 
Burdick, S.M., Ottinger, C., and Brown, D.T., VanderKooi, S.P., Robertson, L., Iwanowicz, D., 2009b, Distribution health and development of larval and juvenile Lost River and shortnose suckers in the Williamson River Delta restoration project and Upper Klamath Lake, Oregon: 2008 Annual Report: U.S. Geological Survey Open-File Report 2009-1287, 88 p.

Bureau of Reclamation, 1997, Upper Klamath Lake and Agency Lake data collection and processing protocol from May -June 1996 bathymetric mapping project. USBR, Flagstaff, Arizona.

Chávez de Martínez, M.C., 1990, Vitamin C requirement of the Mexican native cichlid Cichlasoma urophthalmus (Gunther): Aquaculture, v. 86, p.409-416.

Galeotti, M., Beraldo, P., de Dominis, S., D’Angelo, L., Ballestrazzi, R., Musetti, R., Pizzoloito, S., and Pinosam, M., 2000, A preliminary histological and ultrastructural study of opercular anomalies in gilthead sea bream larvae (Sparus aurata): Fish Physiology and Biochemistry, v. 22, p.151-157.

Hendrixson, H.A., Burdick, S.M., and VanderKooi, S.P., 2007, Near-shore and offshore habitat use by endangered, juvenile Lost River and shortnose suckers in Upper Klamath Lake, Oregon: Annual Report 2004, Report of U.S. Geological Survey, Western Fisheries Research Center, Klamath Falls Field Station to Bureau of Reclamation, Mid-Pacific Region, Klamath Falls, Oregon.

Hilborn, R., and Walters, C.J., 1992, Quantitative Fisheries Stock Assessment: Choice, Dynamics and Uncertainty: Chapman and Hall, New York.

Lindenberg, M.K., Holiman, J.R., and Wood, T.M., 2008, Water quality conditions in Upper Klamath Lake, Oregon, 2006: U.S. Geological Survey Open-File Report 2008-5025, 23 p.

Lindesjoo, E., Thulin, J., Bengtsson, B.E., and Tharnlund, U., 1994, Abnormalities of a gill cover bone, the operculum, in perch Perca fluviatilis from a pulp mill effluent area: Aquatic Toxicology, v. 28, p. 189-207.

Loftus, M.E., 2001, Assessment of potential water quality stress to fish: Report by R2 Resources Consultants to Bureau of Indian Affairs, Portland, Oregon.

MacKenzie, D.L., 2005, Was it there? Dealing with imperfect detection for species presence/absence data: Australian and New Zealand Journal of Statistics, v. 47, p. 65-74.

MacKenzie, D.L., Nichols, J.D., Royle, J.A., Pollock, K.H., Bailey, L.L., and Hines, J.E., 2006, Occupancy estimation and modeling: inferring patterns and dynamics of species occurrence: Elsevier Publishing, San Francisco, California, 324 p.

Markle, D.F., and Clauson, K., 2006, Ontogenetic and habitat-related changed in diet of late larval and juvenile suckers (Catostomidae) in Upper Klamath Lake, Oregon: Western North American Naturalist, v. 66, p. 492-501.

Markle, D.F., Cavalluzzi, M.R, and Simon, D.C., 2005, Morphology and taxonomy of Klamath Basin suckers (Catostomidae): Western North American Naturalist, v. 65, p. 473-489.

Markle, D.F., and Simon, D.C., 1993, Preliminary Studies of Systematics and Juvenile Ecology of Upper Klamath Lake Suckers: Final Report: Oregon State University, Corvallis, Oregon.

Martin, B.A., and Saiki, M.K., 1999, Effects of ambient water quality on the endangered Lost River sucker in Upper Klamath Lake, Oregon: Transactions of the American Fisheries Society, v. 128, p. 953-967.

McCune, B., and Grace, J.B., 2002, Analysis of Ecological Communities: MJM Software Design, Gleneden Beach, Oregon.

National Research Council , 2004, Endangered and threatened fishes in the Klamath River Basin: The National Academies Press, Washington, D.C.

Peterson, J.T., Thurow, R.T., and Guzevich, J.W., 2004, An evaluation of multipass electrofishing for estimating the abundance of stream dwelling salmonids: Transactions of the Amercian Fisheries Society, v. 133, p. 462-475. 
Saiki, M.K., Monda, D.P., and Bellerud, B.L., 1999, Lethal levels of selected water quality variables to larval and juvenile Lost River and shortnose suckers: Environmental Pollution, v.105, p. 37-44.

Simon, D.C., and Markle, D.F., 2001, Ecology of Upper Klamath Lake shortnose and Lost River suckers: Annual survey of abundance and distribution of age-0 shortnose and Lost River suckers in Upper Klamath Lake, 2000 Annual Report: Report of Oregon Cooperative Research Unit, Department of Fisheries and Wildlife, Oregon State University to U.S. Biological Resources Division, U.S. Geological Survey, Corvallis, Oregon and Klamath Project, Bureau of Reclamation, Klamath Falls, Oregon.

Simon, D.C., and Markle, D.F., 2002, Ecology of Upper Klamath Lake shortnose and Lost River suckers: Annual survey of abundance and distribution of age- 0 shortnose and Lost River suckers in Upper Klamath Lake. 2001 Annual Report. Report of Oregon Cooperative Research Unit, Department of Fisheries and Wildlife, Oregon State University to U.S. Biological Resources Division, U.S. Geological Survey, Corvallis, Oregon and Klamath Project, Bureau of Reclamation, Klamath Falls, Oregon.

Simon, D.C., and Markle, D.F., 2006, Ecology of Upper Klamath Lake shortnose and Lost River suckers: Annual survey of abundance and distribution of age- 0 shortnose and Lost River suckers in Upper Klamath Lake. 2005 Annual Report. Report of Oregon Cooperative Research Unit, Department of Fisheries and Wildlife, Oregon State University to U.S. Biological Resources Division, U.S. Geological Survey, Corvallis, Oregon and Klamath Project, Bureau of Reclamation, Klamath Falls, Oregon.

Simon, D.C., and Markle, D.F., 2008, Ecology of Upper Klamath Lake shortnose and Lost River suckers: Annual survey of abundance and distribution of age- 0 shortnose and Lost River suckers in Upper Klamath Lake. 2007 Annual Report. Report of Oregon Cooperative Research Unit, Department of Fisheries and Wildlife, Oregon State University to U.S. Biological Resources Division, U.S. Geological Survey, Corvallis, Oregon and Klamath Project, Bureau of Reclamation, Klamath Falls, Oregon.

Simon, D.C., Terwilliger, M.R., Murtaugh, P., and Markle, D.F., 2000a, Larval and juvenile ecology of Upper Klamath Lake suckers: 1995-1998: Corvallis, Oreg., Department of Fisheries and Wildlife, Oregon State University.

Simon, D.C., Terwilliger, M.R., and Markle, D.F., 2000b, Ecology of Upper Klamath Lake shortnose and Lost River suckers: Annual survey of abundance and distribution of age-0 shortnose and Lost River suckers in Upper Klamath Lake, 1999 Annual Report: Report of Oregon Cooperative Research Unit, Department of Fisheries and Wildlife, Oregon State University to U.S. Biological Resources Division, U.S. Geological Survey, Corvallis, Oregon and Klamath Project, Bureau of Reclamation, Klamath Falls, Oregon.

Terwilliger, M.R., Simon, D.C., and Markle, D.F., 2004, Larval and juvenile ecology of Upper Klamath Lake suckers, 1995-2003: Corvallis, Oreg., Oregon Cooperative Research Unit, Department of Fisheries and Wildlife, Oregon State University.

Terwilliger, M.R., Simon, D.C., and Markle, D.F., 2008, Ecology of Upper Klamath Lake Shortnose and Lost River Suckers, 2006 Annual Report: Report of Oregon Cooperative Research Unit, Department of Fisheries and Wildlife, Oregon State University to U.S. Biological Resources Division, U.S. Geological Survey, Corvallis, Oregon and Klamath Project, Bureau of Reclamation, Klamath Falls, Oregon.

Tringali, M., Ziemann, D., and Struck, K., 2001, Preliminary Aspects of Genetic Management for Pacific Threadfin Polydactylus sexfilis Stock Enhancement Research in Hawaii: Ecology of 
aquaculture species and enhancement of stocks proceedings of the thirtieth U.S. Japan meeting on aquaculture, Sarasota, Florida.

U.S. Geological Survey, 2004, Klamath area, Oregon [map]: 1:24,000. 7.5 Minute Series, Washington D.C.: USGS, downloaded November 2004.

U.S. Geological Survey, 2009, National Water Information System Web Interface. http://waterdata.usgs.gov/nwis/nwisman/?site_no=11502500\&agency_cd=USGS. Accessed on August 11, 2009.

VanderKooi, S.P., and Buelow, K.A., 2003, Near-shore habitat use by endangered juvenile suckers in Upper Klamath Lake, Oregon: Annual Report 2001: U.S. Geological Survey, Western Fisheries Research Center, Klamath Falls Field Station, Klamath Falls, Oregon.

VanderKooi, S.P., Herring, B.L., Coshow, R.H., and Hendrixson, H.A., 2006, Near-shore habitat use by endangered juvenile suckers in Upper Klamath Lake, Oregon: Annual Report 2002-2003: U.S. Geological Survey, Western Fisheries Research Center, Klamath Falls Field Station, Klamath Falls, Oregon.

Weir, L.A., Royle, J.A., Nanjappa, P., and Jung, R.E., 2005, Modeling anuran detection and site occupancy on North American amphibian monitoring program (NAAMP) routes in Maryland: Journal of Herpetology, v. 39, p. 627-639.

Winemiller, K.O., and Taylor, D.H., 1982, Inbreeding depression in the convict cichlid, Cichlasoma nigrofasciatum (Baird and Girard): Journal of Fish Biology, v. 21, p. 399-402.

Wood, T.M., Holiman, G.H., and Lindenberg, M.K., 2006, Water quality conditions in Upper Klamath Lake, Oregon, 2002-2004: U.S. Geological Survey Open-File Report 2006-5209, 49 p.

Wood, T.M., Cheng, R.T., Gartner, J.W., Holiman, G.R., Lindenberg, M.K., Wellman, R.E., 2008, Modeling hydrodynamics and heat transport in Upper Klamath Lake, Oregon, and implications for water quality: U.S. Geological Survey Open-File Report 2008-5076, 49 p. 


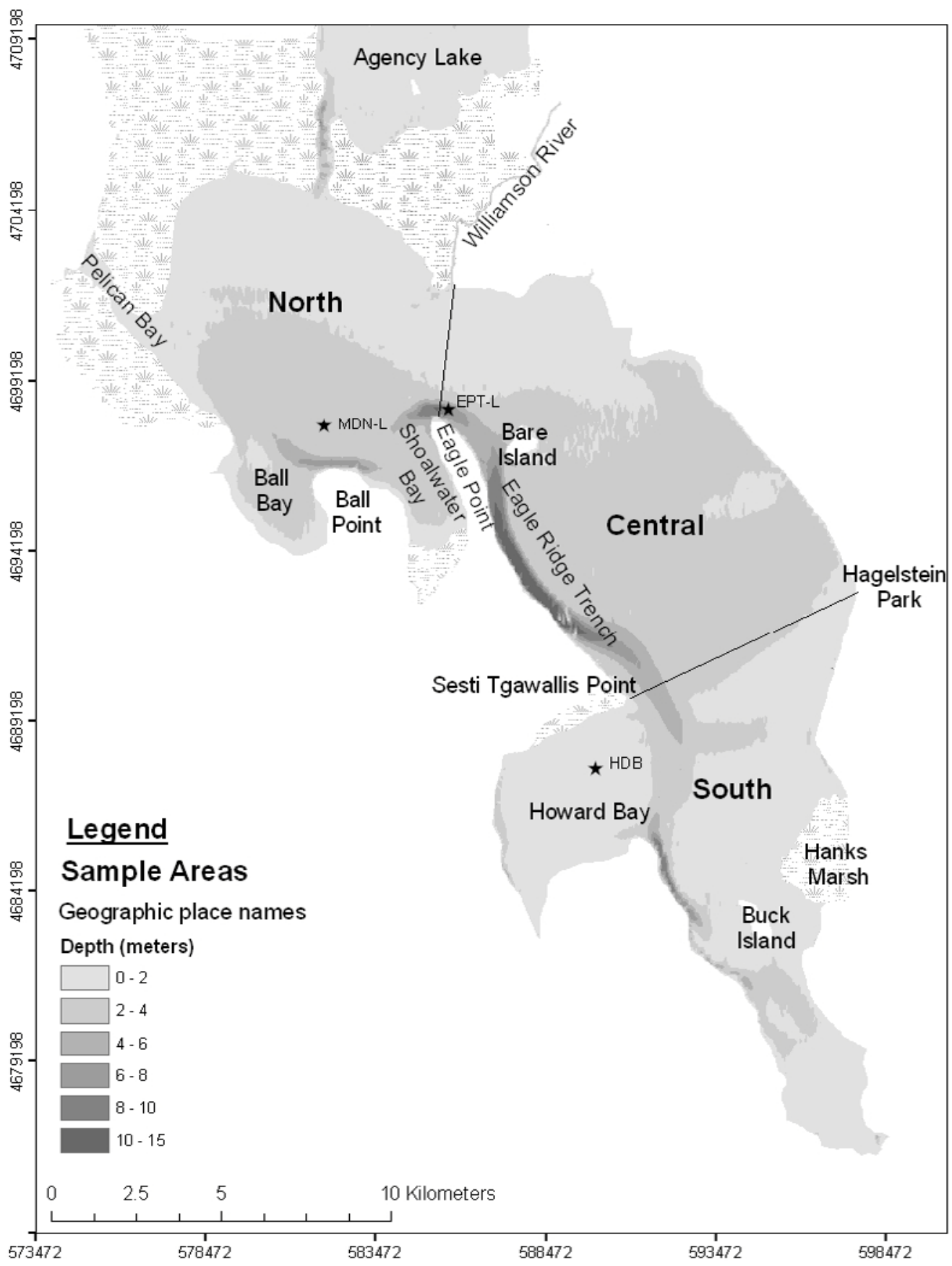

Figure 1. Map of Upper Klamath Lake study area and three defined areas of the lake. Sample sites were selected randomly from six strata, including both near and off-shore strata in the north, central, and south parts of the lake. Near-shore strata were considered areas within 100 meters of shore, whereas off-shore strata are areas more than 100 meters from shore. The lake was stratified by area to provide good coverage of the entire lake. Bathymetry layer is from U.S. Geological Survey (2004). Water-quality monitoring sites are shown with a star. 

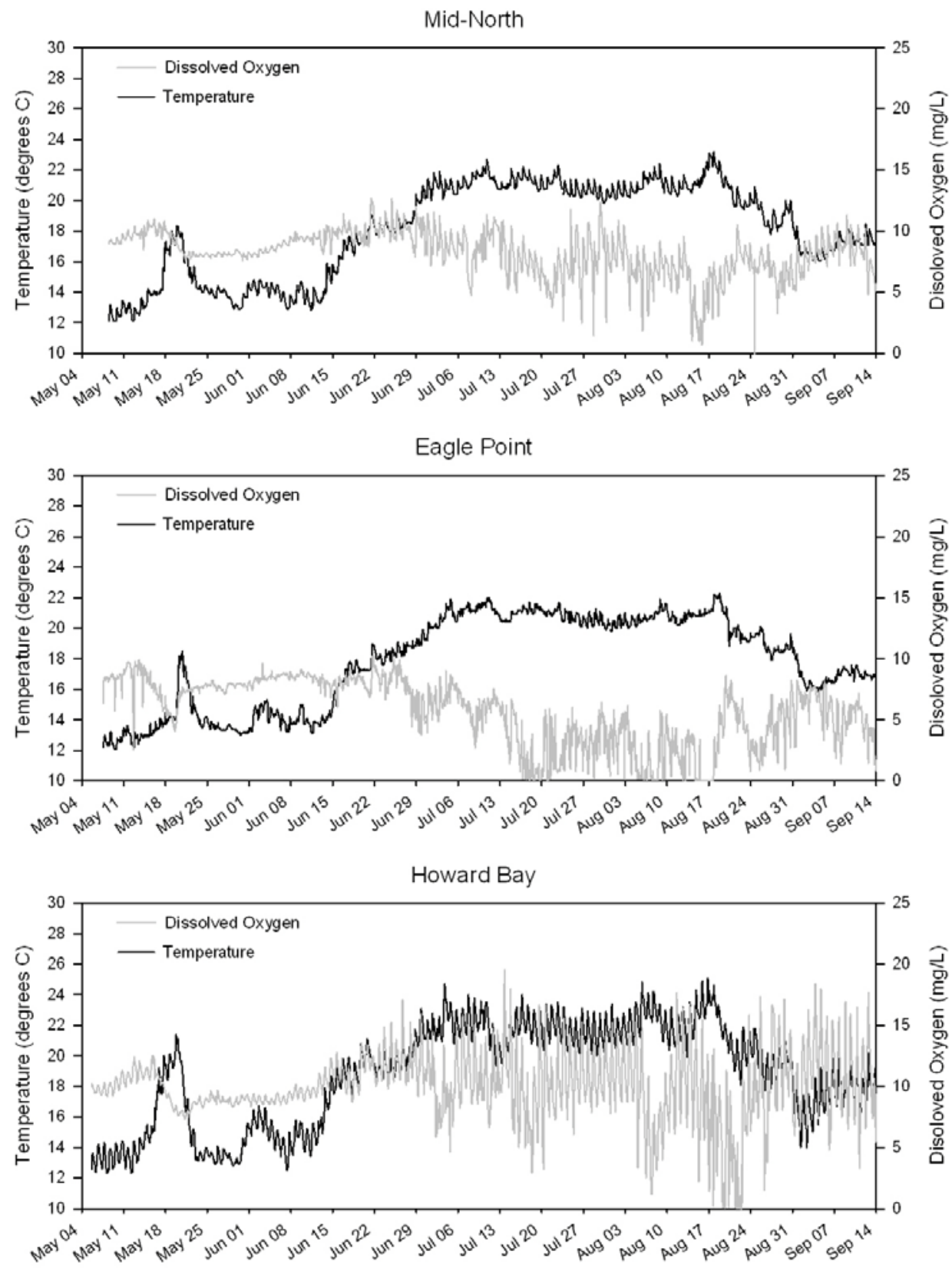

Figure 2. DO concentrations (grey) and temperature (black) recorded each hour at three water-quality monitoring stations in Upper Klamath Lake, Oregon (U.S. Geological Survey, 2009). The location of these water-quality monitoring stations are shown in figure 1. These stations were selected to represent conditions in Eagle Ridge Trench (Eagle Point station), Howard Bay, and the area of Upper Klamath Lake located east of Ball Bay, Shoalwater Bay, Howard Bay, and Eagle Ridge Trench, and north of Buck Island. 


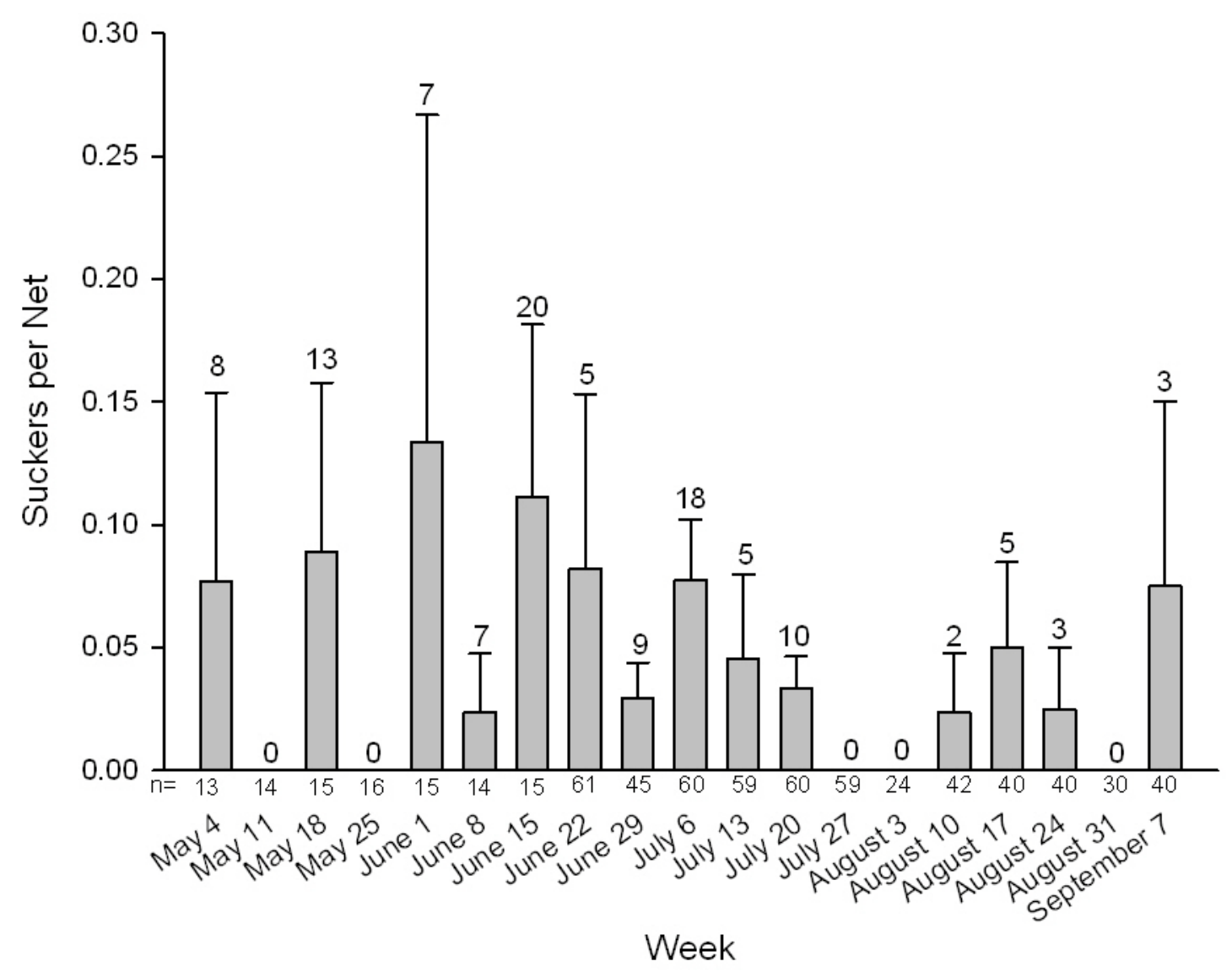

Figure 3. Mean $( \pm \mathrm{SE}$ ) weekly catch per unit effort (suckers per net) for age-1 suckers caught in trap nets set overnight in Upper Klamath Lake, Oregon, between May 5 and September 13, 2008. The percentage of sites at which at least one sucker was caught and the number of sites sampled each week are given above and below the $x$-axis, respectively. At each site, between one and three nets were set. 


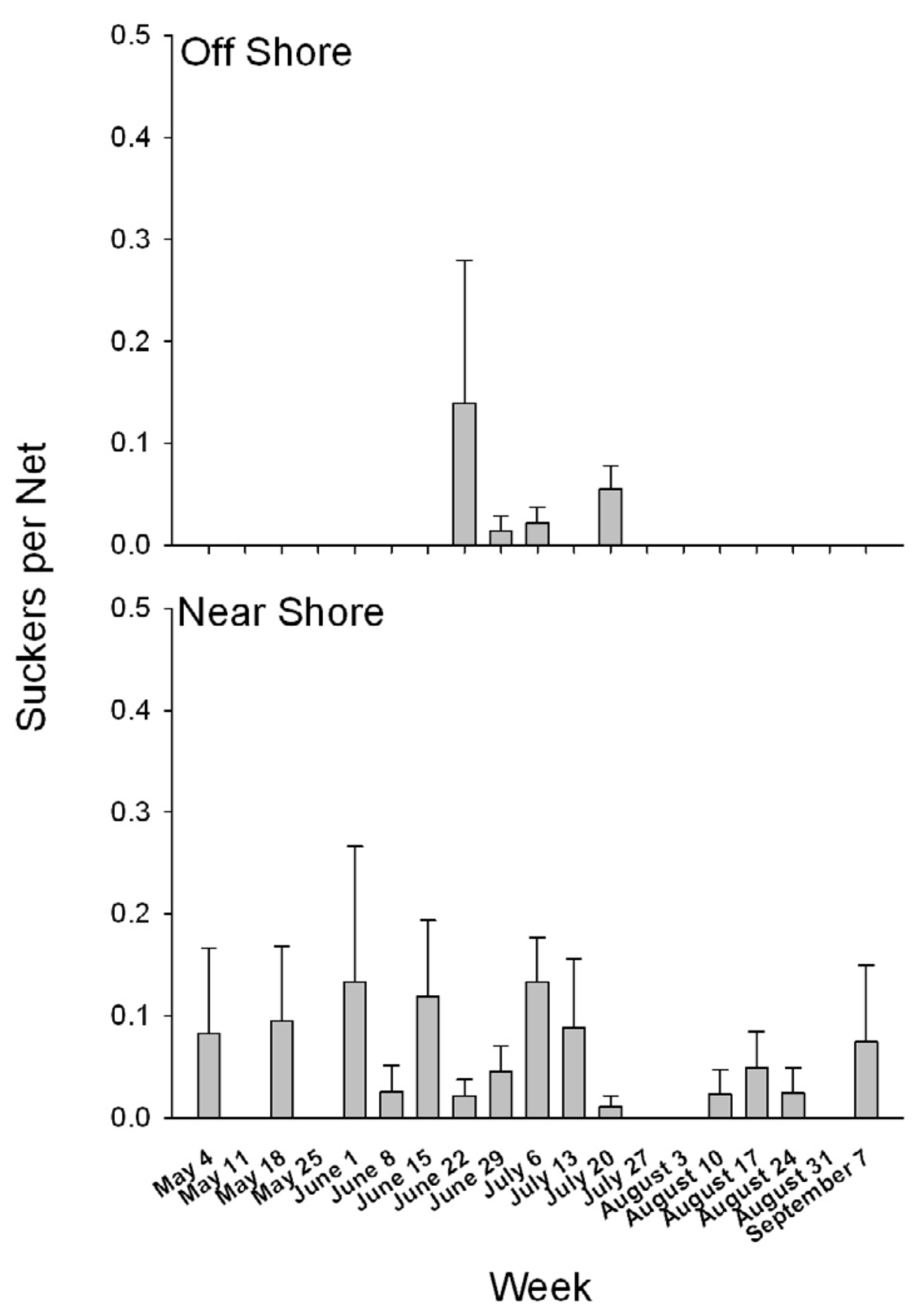

Figure 4. Mean $( \pm S E)$ weekly catch per unit effort (suckers per net) for age-1 suckers caught in trap nets set overnight in Upper Klamath Lake, Oregon, between May 5 and September 13, 2008. Sites located within 100 meters of shore (near-shore) are shown separately from sites located more than 100 meters from shore (off-shore). The percentage of sites at which at least one sucker (naïve occupancy rate) was caught and the number of sites sampled each week are given above and below the $x$-axis, respectively. At each site, between one and three nets were set. 


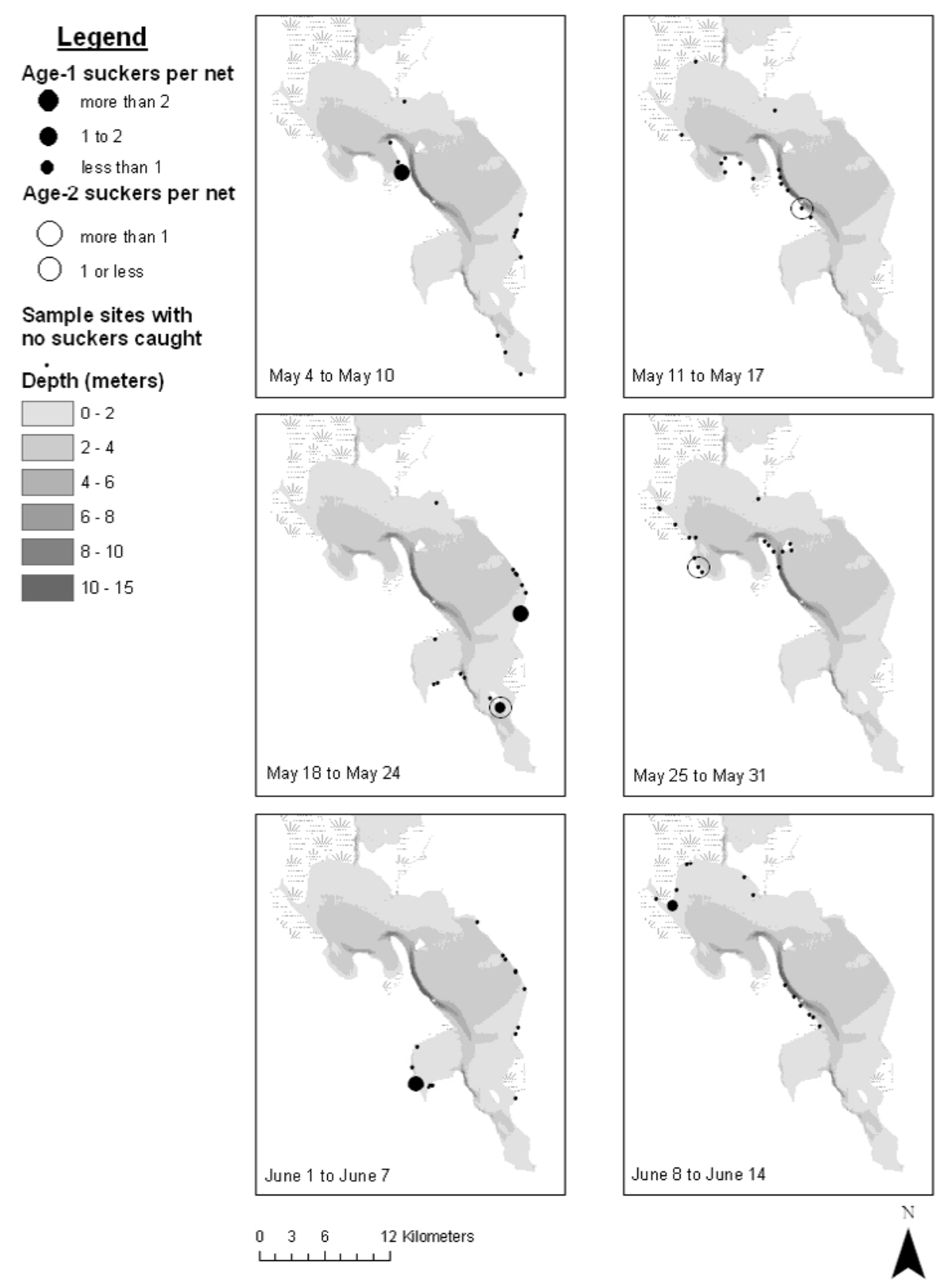

Figure 5. Location of sample sites and age-1 and age-2 sucker catch rates in Upper Klamath Lake, Oregon, by week. Suckers were sampled between May 4 and September 13, 2008, using trap nets set overnight on the bottom of the lake. Sample sites were selected to examine shoreline distributions of suckers between May 4 and June 21 and between August 3 and September 13. June 22 and August 2 sample locations were selected to examine lakewide distributions of suckers. Bathymetry layer is from Bureau of Reclamation (1997). 

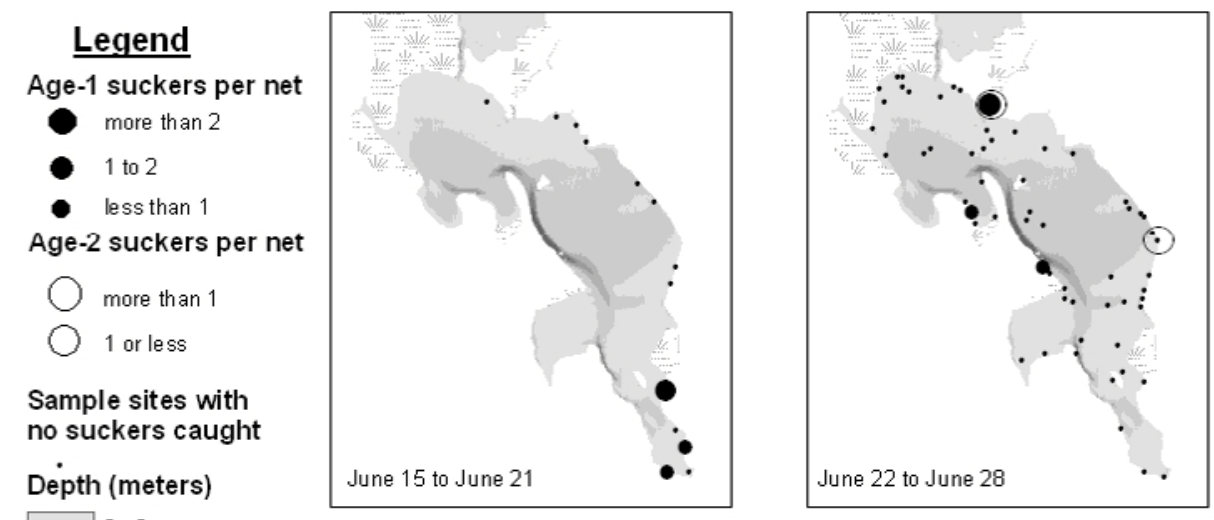

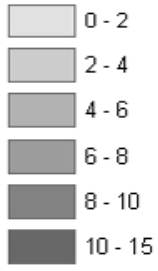
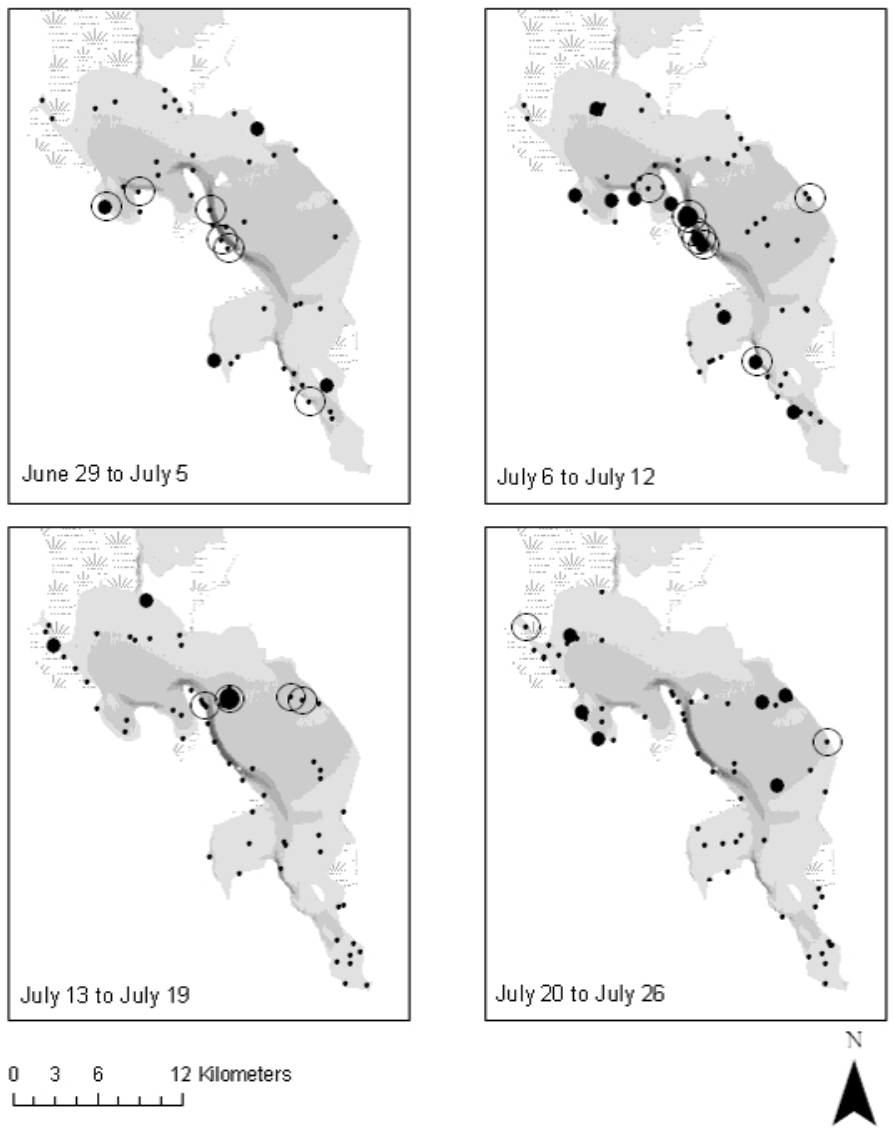

Figure 5. Continued 


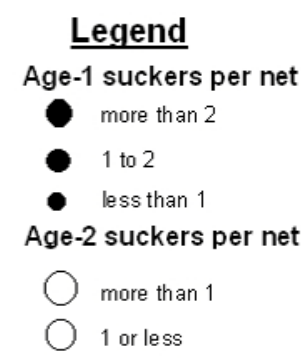

Sample sites with no suckers caught

Depth (meters)

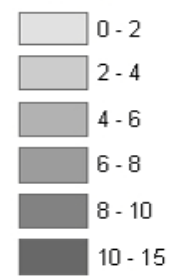
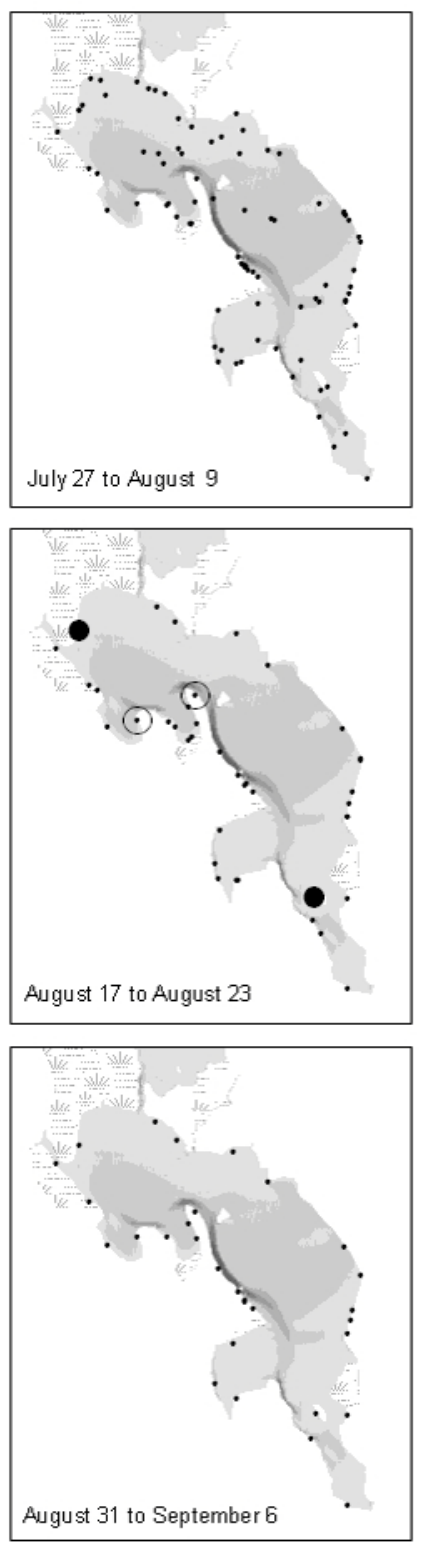

$\begin{array}{lll}0 & 3 & 6\end{array}$ 12 Klometers
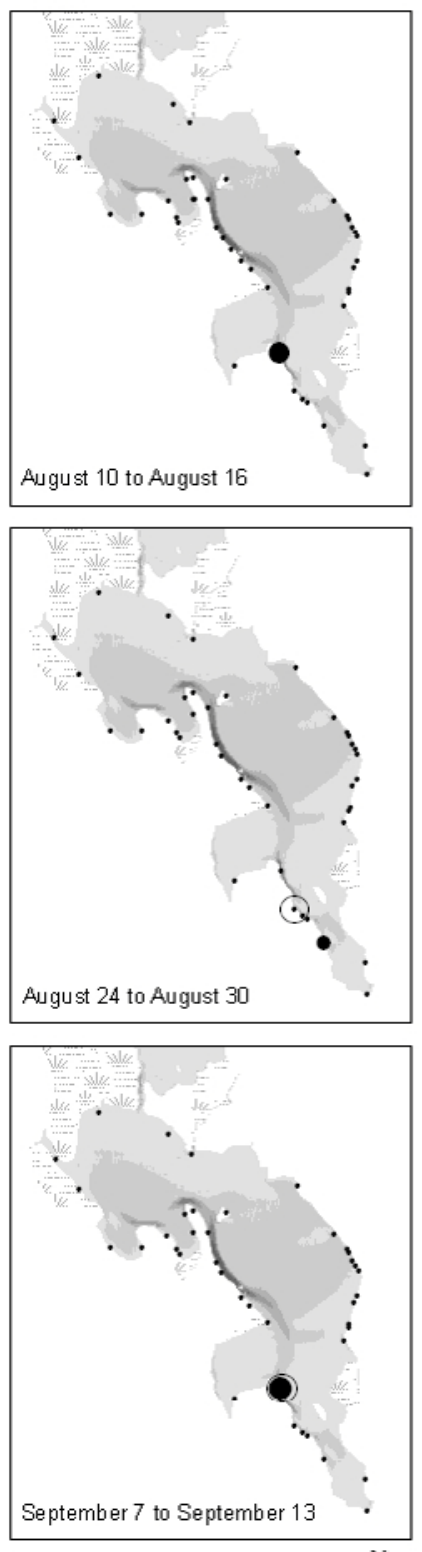

$\wedge$

Figure 5. Continued 

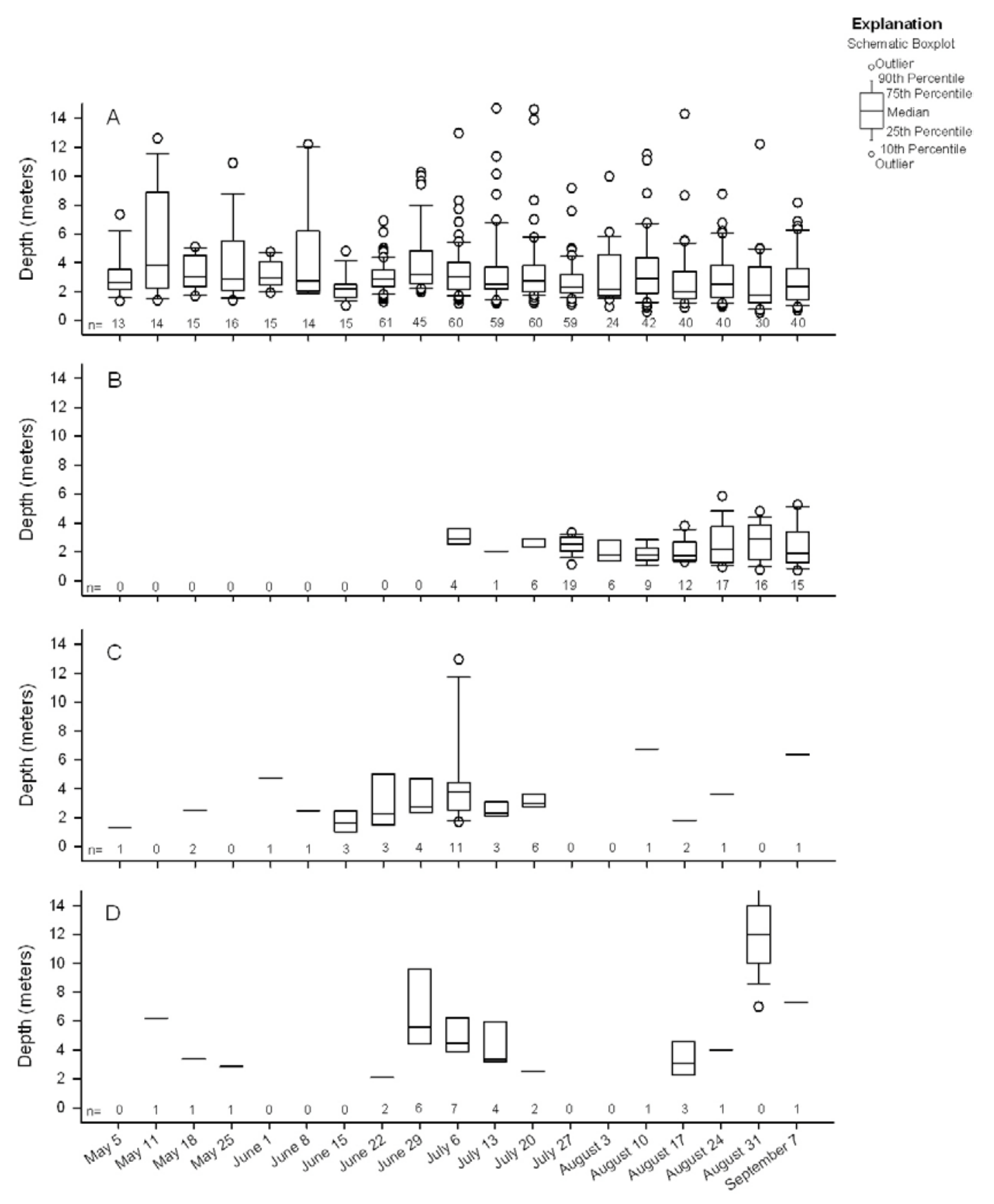

Figure 6. Depth for trap net sample sites (A), sites where age-0 suckers were caught (B), sites where age-1 suckers were caught $(C)$, and sites where age-2 suckers were caught (D) are shown by week. Suckers were collected in trap nets set overnight in Upper Klamath Lake, Oregon between May 5 and September 13, 2008. The weekly sample sizes given along the $x$ axes (n), are for all sites sampled in plot $A$, and only for the sites where suckers were caught in graphs $B, C$, and $D$. 


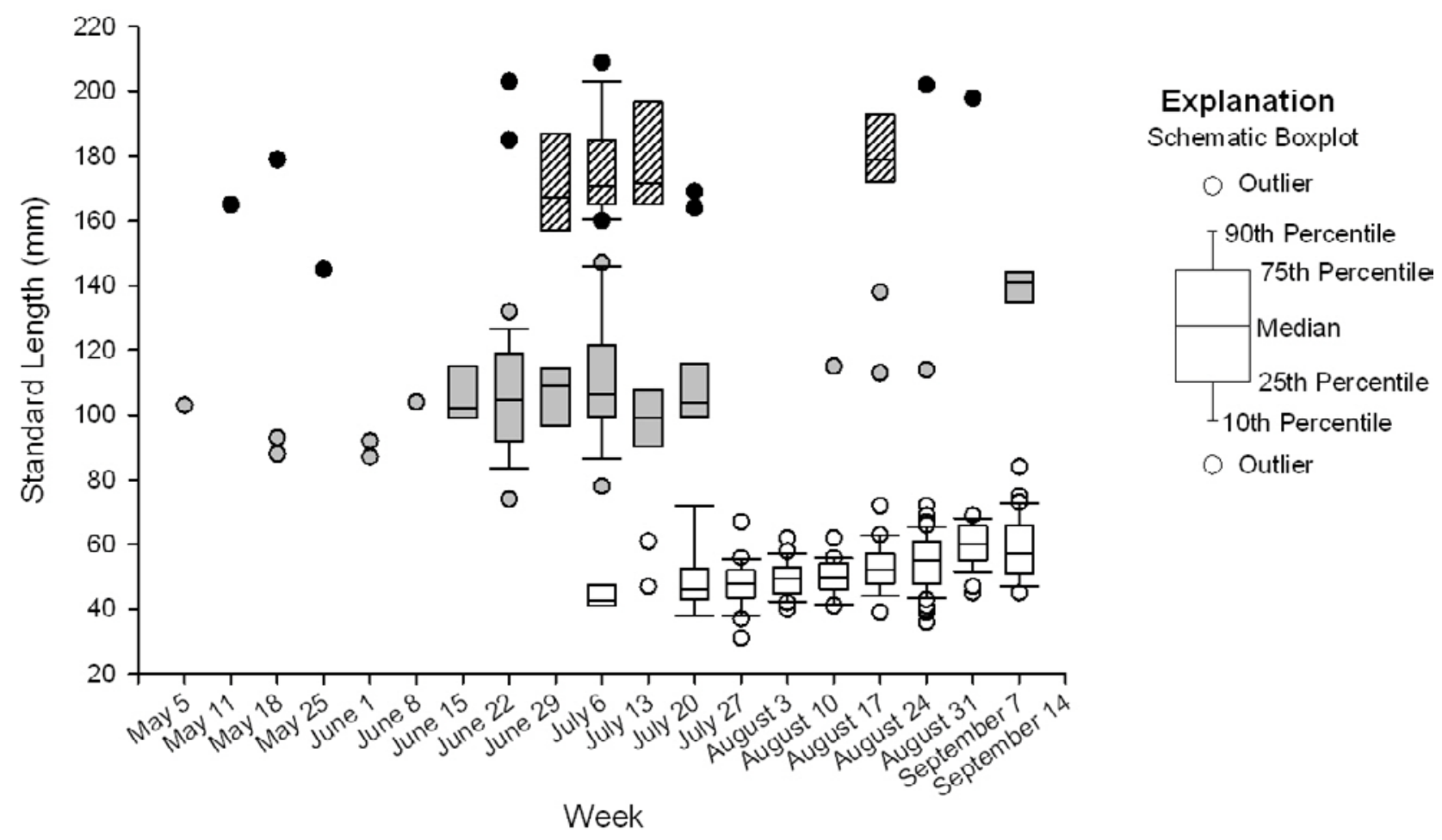

Figure 7. Standard lengths of juvenile suckers collected in traps nets set in Upper Klamath Lake, Oregon, between May 5 and September 12, 2008. Three age classes are shown; age-0 suckers (white), age-1 suckers (grey), and age-2 or older suckers (black stripes). 

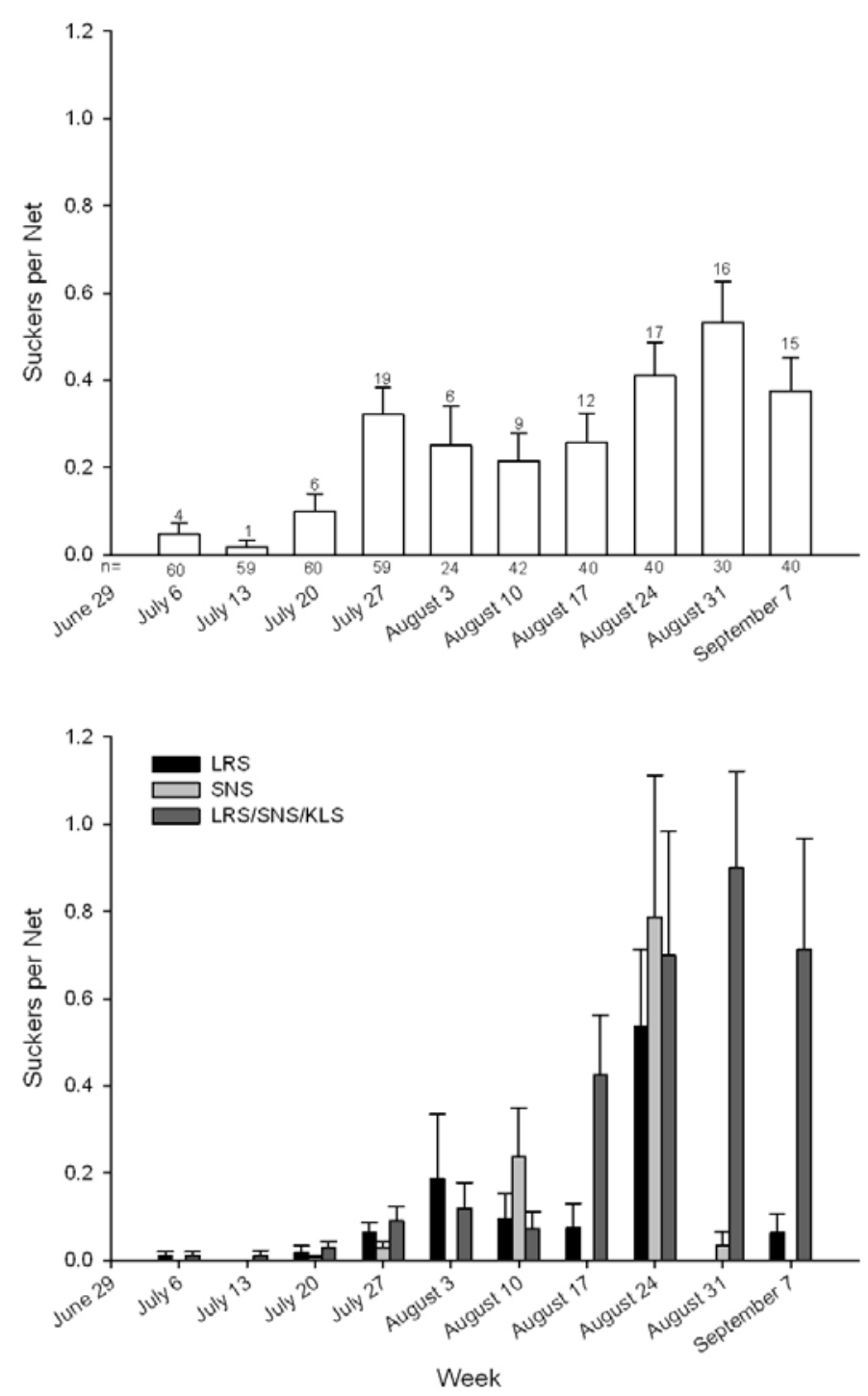

Figure 8. Mean $( \pm S E)$ weekly catch per unit effort (suckers per net) for age-0 suckers caught in trap nets set overnight in Upper Klamath Lake, Oregon, between June 22 and September 13, 2008 (top). The percentage of sites at which at least one sucker was caught (naïve occupancy rate) and the number of sites sampled each week are given above and below the $x$-axis, respectively. Mean $( \pm$ SE) weekly catch per unit effort for age-0 Lost River sucker (LRS, black), shortnose suckers (SNS, white), and suckers with characteristics of Lost River, shortnose or Klamath largescale suckers (LRS/SNS/KLS, grey) are also shown for the same time period (bottom). Juvenile suckers must be sacrificed for species identification. Therefore, to estimate catch per unit effort (suckers per net) for each species caught, we extrapolated using species identifications determined from a subset of sacrificed suckers equal to approximately one-third of the total catch. 

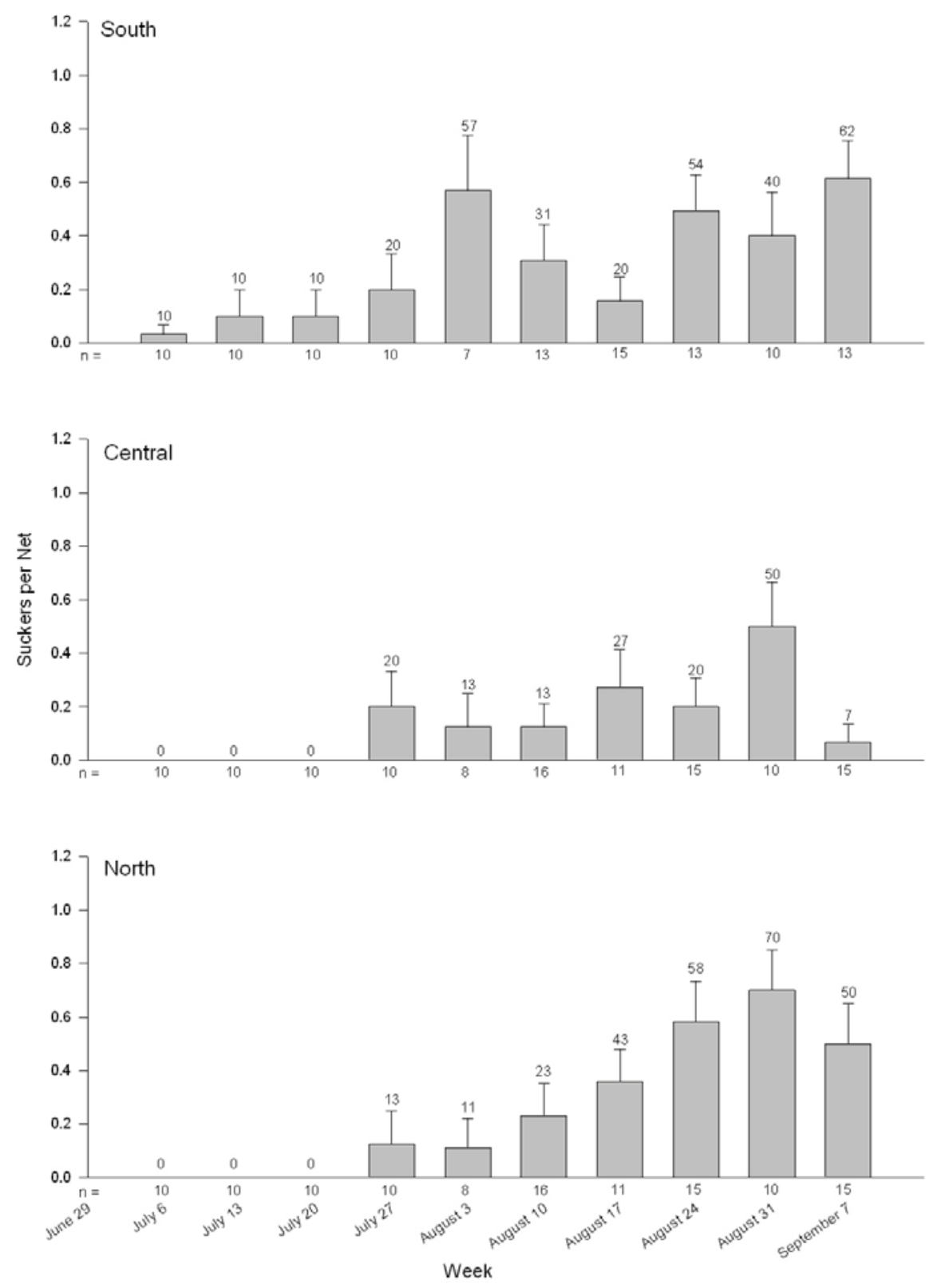

Figure 9. Mean ( \pm SE) weekly catch per unit effort (suckers per net) for age-0 suckers caught in trap nets in three off-shore areas of Upper Klamath Lake, Oregon (fig. 1), between June 22 and August 2, 2008. Sample sites considered to be off-shore were more than 100 meters of shore. The percentages of sites at which least one sucker was caught and numbers of sites sampled each week are given above and below the $x$-axis, respectively. Offshore areas were not sampled after August 2. Between one and three nets were sampled at each site (table 2). Dates given are for the Sunday that started each week. 

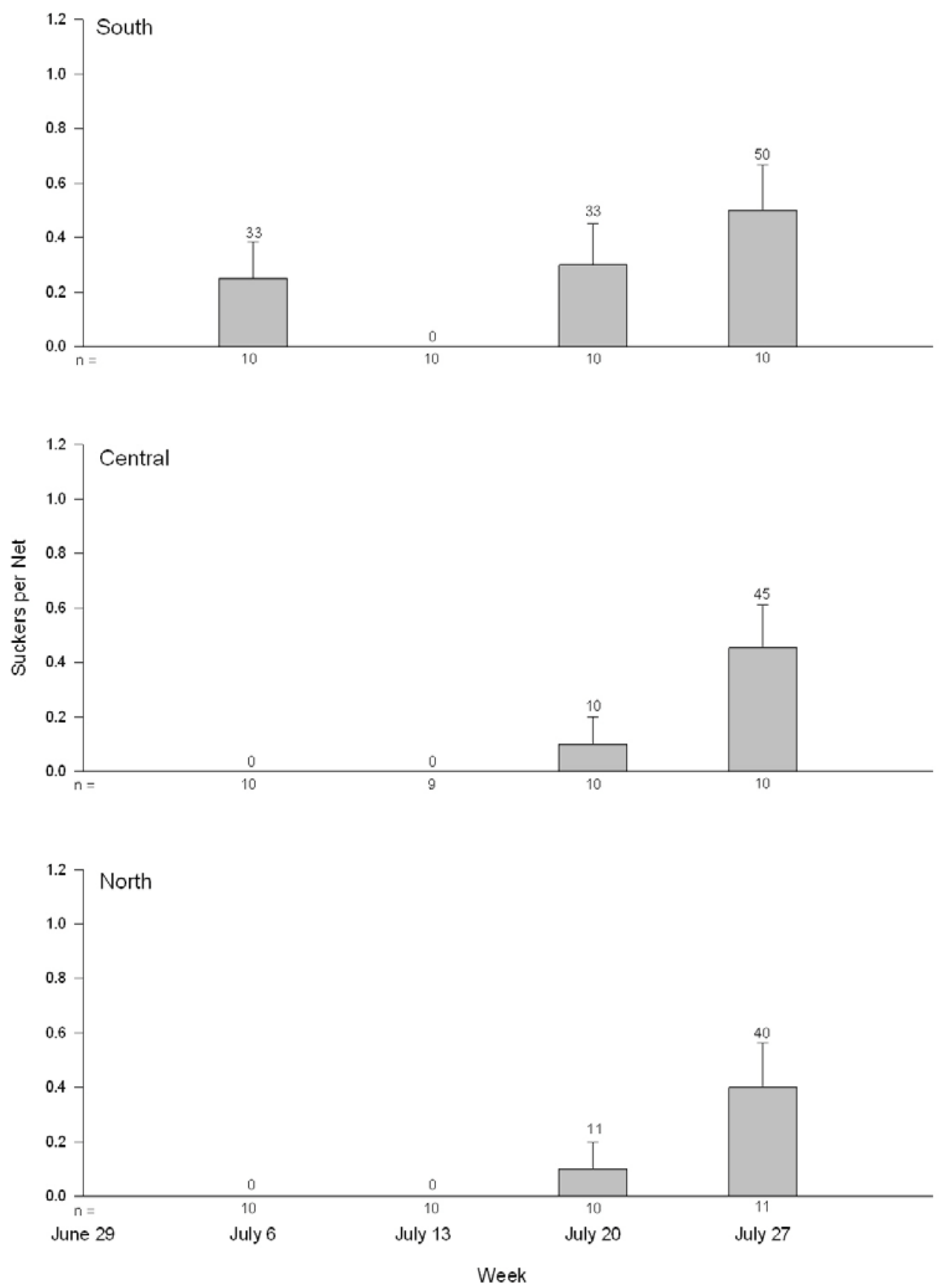

Figure 10. Mean ( \pm SE) weekly catch per unit effort (suckers per net) for age-0 suckers caught in trap nets in three near-shore areas of Upper Klamath Lake, Oregon (fig. 1), between June 22 and September 13, 2008. Sample sites considered to be near-shore were within 100 meters of shore. The percentages of sites at which least one sucker was caught and numbers of sites sampled each week are given above and below the x-axis, respectively. Between one and three nets were sampled at each site (table 2). Dates given are for the Sunday that started each week. 

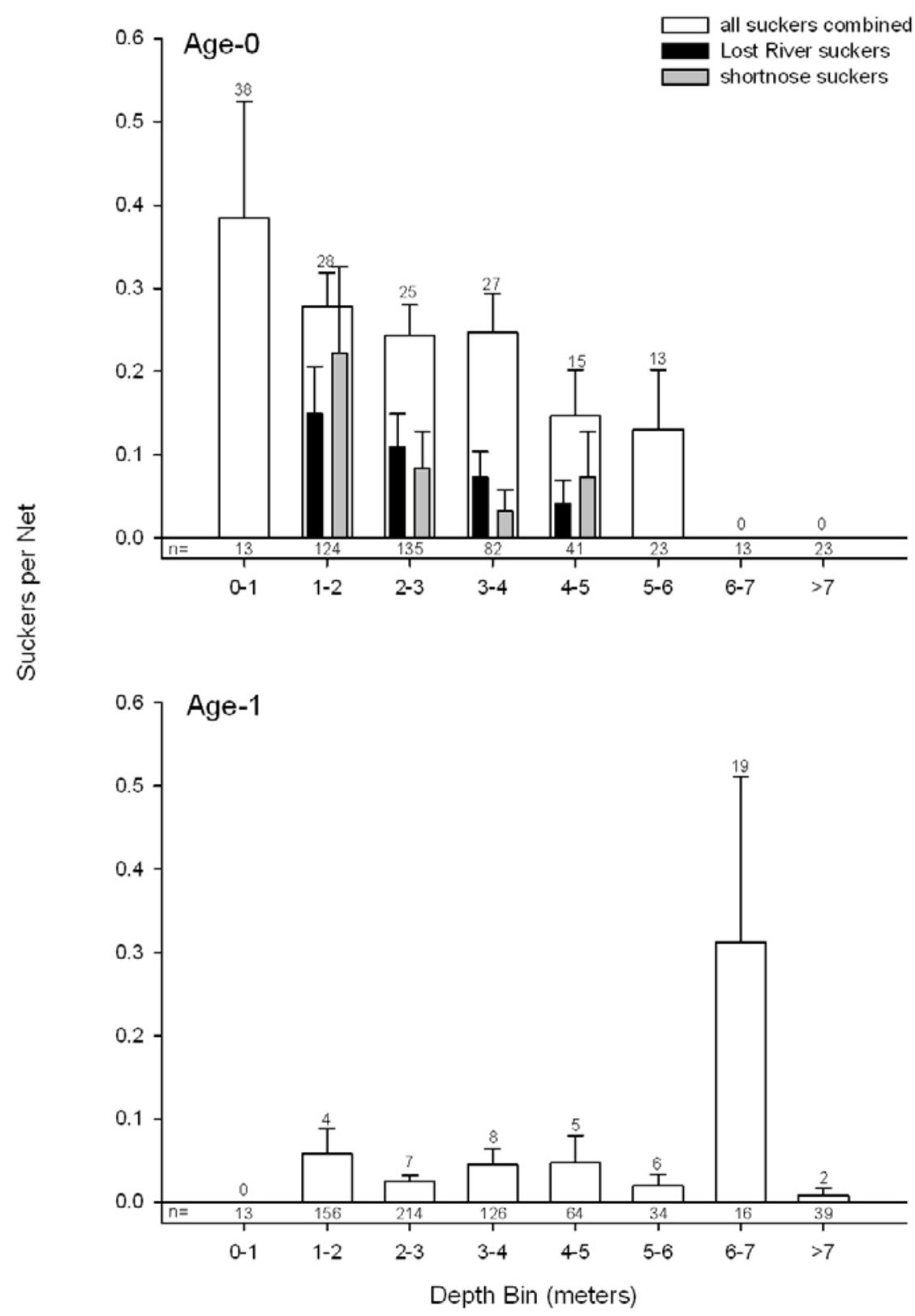

Figure 11. Mean ( \pm SE) catch per unit effort (CPUE: suckers per net) by 1 meter depth bins for age-0 (top) and age-1 (bottom) suckers caught in Upper Klamath Lake, Oregon. The sample sites used in preparation of this figure were limited to those sampled between the first and last capture of suckers in each age group. Therefore, for age-0 suckers only sites sampled between July 6 and September 13 were used and for age-1 suckers only sites sampled between May 11 and July 20 were used. The percentages of sites in each depth category at which at least one sucker was caught are given (above the bars) and the number of sites sampled in each depth category (above the $x$-axis). One in every three age-0 suckers were sacrificed to species. The catch per unit effort for sacrificed age-0 identified to species is shown (top). 

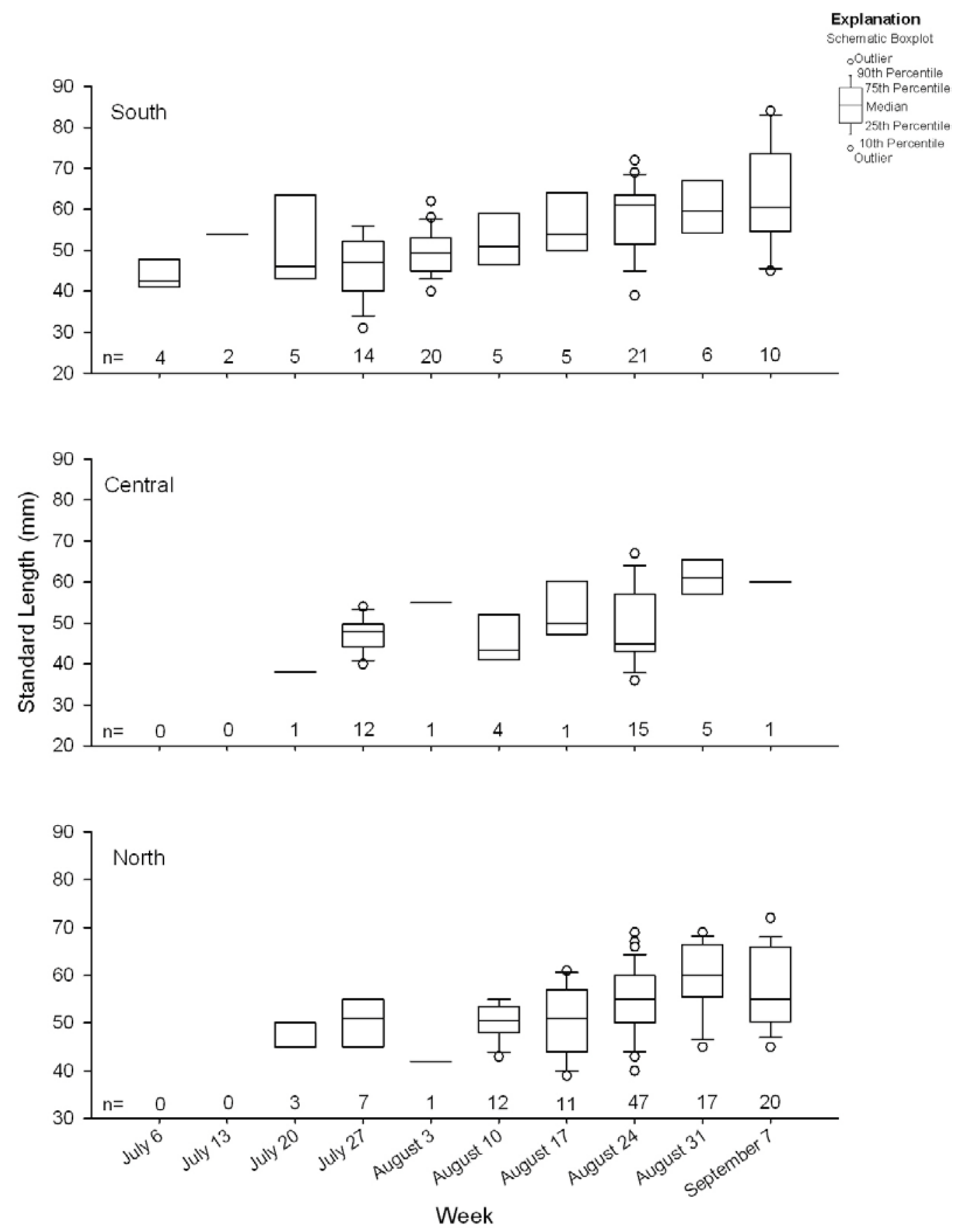

Figure 12. Standard length ( $\mathrm{mm}$ ) of age-0 suckers caught in trap net sampling in three areas (fig. 1) of Upper Klamath Lake, Oregon, between July 6 and September 13, 2008. The numbers of age-0 suckers caught each week in each area and used in the creation of each box plot are given along the $x$-axis. 

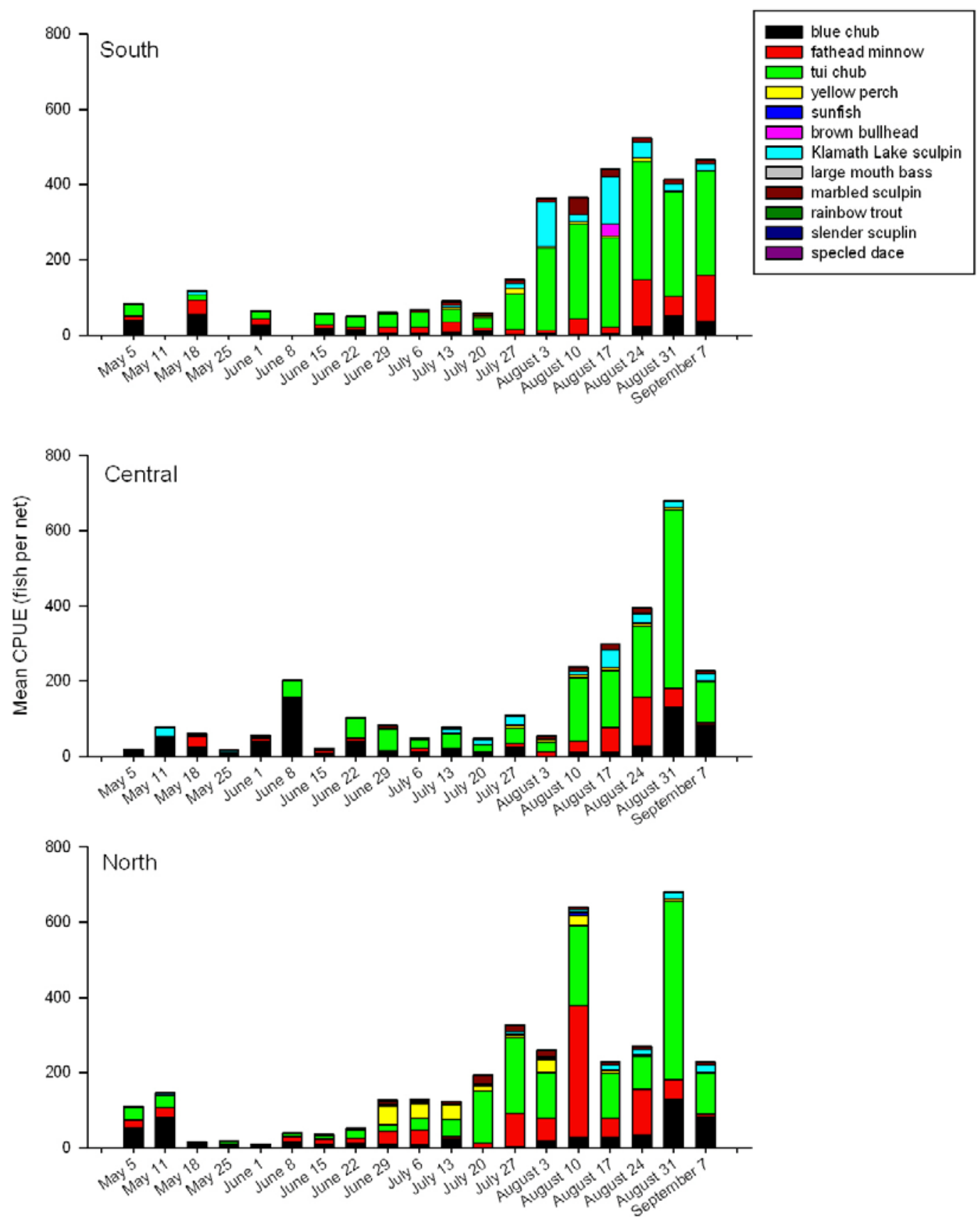

Figure 13. Mean weekly catches of fish other than sucker species captured in trap nets set overnight in three areas of Upper Klamath Lake, Oregon (fig. 1). 
Table 1. Number of sample sites for juvenile fish visited one to six times in Upper Klamath Lake, Oregon, 2008. [At each site, between one and three trap nets were set overnight between May 5 and September 11]

\begin{tabular}{cc}
\hline Repeat visits & Number of sites \\
\hline 1 & 250 \\
2 & 40 \\
3 & 20 \\
4 & 40 \\
5 & 20 \\
6 & 2 \\
Total sites & 372 \\
\hline
\end{tabular}


Table 2. Number of sites at which one, two, or three nets were set in three seasons, and in six strata Upper Klamath Lake, Oregon, 2008.

[Seasons are defined as spring (May 5-June 19), mid-summer (June 23-July 31), and late summer (August 4- September 25). Seven nets set during the mid-summer time period failed to effectively sample fish and were removed from the dataset]

\begin{tabular}{|c|c|c|c|c|}
\hline \multirow{2}{*}{ Strata } & \multicolumn{3}{|c|}{ Number of nets } & \multirow{2}{*}{ Total sites } \\
\hline & 1 & 2 & 3 & \\
\hline \multicolumn{5}{|c|}{ Spring } \\
\hline Central Near-shore & 28 & 0 & 6 & 34 \\
\hline Central Off-shore & 3 & 0 & 0 & 3 \\
\hline North Near-shore & 18 & 0 & 8 & 26 \\
\hline North Off-shore & 3 & 0 & 0 & 3 \\
\hline South Near-shore & 26 & 0 & 10 & 36 \\
\hline Spring Total & 78 & 0 & 24 & 102 \\
\hline \multicolumn{5}{|c|}{ Mid-summer } \\
\hline Central Near-shore & 0 & 0 & 58 & 58 \\
\hline Central Off-shore & 0 & 0 & 59 & 59 \\
\hline North Near-shore & 0 & 1 & 55 & 56 \\
\hline North Off-shore & 0 & 2 & 54 & 56 \\
\hline South Near-shore & 1 & 0 & 55 & 56 \\
\hline South Off-shore & 0 & 0 & 59 & 59 \\
\hline Mid-Summer Total & 1 & 3 & 340 & 344 \\
\hline \multicolumn{5}{|c|}{ Late summer } \\
\hline Central Near-shore & 70 & 0 & 5 & 75 \\
\hline North Near-shore & 65 & 0 & 5 & 70 \\
\hline South Near-shore & 64 & 0 & 7 & 71 \\
\hline Late Summer Total & 199 & 0 & 17 & 216 \\
\hline Total & 278 & 3 & 381 & 662 \\
\hline
\end{tabular}


Table 3. Age-1 and age-2 suckers per net captured in trap net sampling in Upper Klamath Lake, Oregon, between May 5 and June 19, 2008.

[Trap nets were set overnight in five strata including near and off-shore strata in the central and north portions of the lake (fig. 1), and near-shore in the south portion of the lake. Near-shore sites were within 100 meters of shore, whereas off-shore sites were more than 100 meters from shore]

\begin{tabular}{lccc}
\hline \multirow{2}{*}{ Strata } & \multirow{2}{*}{ Number of nets } & \multicolumn{2}{c}{ Suckers per net } \\
\cline { 2 - 4 } & & Age-1 & Age-2 \\
\hline South Near-shore & 58 & 0.12 & 0.02 \\
South Off-shore & 0 & 0.00 & 0.00 \\
Central Near-shore & 46 & 0.00 & 0.02 \\
Central Off-shore & 3 & 0.00 & 0.00 \\
North Near-shore & 42 & 0.05 & 0.02 \\
North Off-shore & 3 & 0.00 & 0.00 \\
\hline
\end{tabular}


Publishing support provided by the U.S. Geological Survey Publishing Network, Tacoma Publishing Service Center

For more information concerning the research in this report, contact the Director, Western Fisheries Research Center

U.S. Geological Survey, 6505 NE 65th Street

Seattle, Washington 98115

http://wfrc.usgs.gov/ 
